\title{
Diverse Molecular Targets for Chalcones with Varied Bioactivities
}

\section{Bo Zhou and Chengguo Xing}

Department of Medicinal Chemistry, College of Pharmacy, University of Minnesota, Minneapolis, USA

\begin{abstract}
Natural or synthetic chalcones with different substituents have revealed a variety of biological activities that may benefit human health. The underlying mechanisms of action, particularly with respect to the direct cellular targets and the modes of interaction with the targets, have not been rigorously characterized, which imposes challenges to structure-guided rational development of therapeutic agents or chemical probes with acceptable target-selectivity profile. This review summarizes literature evidence on chalcones' direct molecular targets in the context of their biological activities
\end{abstract}

\section{Keywords: Chalcone; Molecular target; Mechanism of action}

\section{Introduction}

Chalcone or (E)-1,3-diphenyl-2-propene-1-one, is an important chemotype that has attracted great research interest for decades due to the high natural abundance of chalcone compounds, their easy synthesis, and most importantly, their diverse biological activities. Indeed, many natural chalcones demonstrated a wide variety of bioactivities, including anti-cancer, anti-inflammatory, anti-diabetic, cancer chemopreventive, anti-oxidant, and anti-microbial activities (Figure 1A) [1-3]. In many cases, a single compound exhibits several bioactivities. For example, xanthohumol revealed anti-cancer, cancer chemopreventive, antioxidant, and anti-inflammatory activities; isoliquiritigenin showed anti-inflammatory, anxiolytic, and anti-pigmentation activities; and isobavachalcone demonstrated chemopreventive, anti-cancer, antibacterial and anti-fungal activities [1]. Several chalcone compounds have been marketed or clinically tested for various health conditions (e.g., metochalcone - choleretic/diuretic; sofalcone - anti-ulcer/ mucoprotective; and hesperidin methylchalcone - vascular protective), exemplifying the clinical potential of chalcones (Figure 1B) [2].

The wide bioactivity spectrum of chalcones, on the other hand, also indicates a potentially promiscuous target profile, which presents a challenge for their clinical development. Therefore, knowledge of chalcones' mechanisms and direct molecular targets is particularly important for the future development of clinically useful chalcone compounds. A great number of reports have attempted to reveal mechanisms responsible for chalcones' various bioactivities. Some of such mechanistic knowledge has been extensively reviewed, including anti-cancer [3-9], anti-inflammatory [9-11], and anti-diabetic activities [12], which will not be the focus of this review. Similarly, many potential direct molecular targets have been identified, yet have not been systematically reviewed. This review, therefore, summarizes the current knowledge of potential molecular targets that chalcones directly interact with. Various levels of experimental evidence of direct interaction and the biological relevance of these interactions is discussed. Due to the scope of this review, compounds derived from chalcone but do not contain the intact chalcone scaffold are not included.

\section{Molecular Targets of Chalcones}

\section{Microtubule}

Microtubule is the key component of mitotic spindles during cell proliferation. It is formed by heterodimers of $\alpha$ - and $\beta$-tubulin through a highly dynamic polymerization-depolymerization process. Antimicrotubule agents, which interact with microtubule and disturb such a dynamic process, typically cause cell cycle arrest. Anti-microtubule agents therefore are potential anticancer drugs; indeed paclitaxel, vinblastine, ixabepilone, and other anti-microtubule agents have been used clinically to treat a variety of malignancies $[13,14]$.

A number of chalcone compounds have been shown to be potential anti-microtubule agents. The earliest example is compound 1 (MDL27048). Peyrot et al. [15,16] found that this synthetic cytotoxic compound rapidly and reversibly bound to purified tubulin, inhibited tubulin polymerization into microtubule, and disrupted microtubule structure and arrested mitosis in vitro. Taking advantage of the change in spectroscopic properties (absorption and fluorescence) upon tubulin binding, 1 has been characterized as a single-site ligand of tubulin with a binding affinity of $2.8 \times 10^{6} \mathrm{M}^{-1}$. Classical colchicine binding site ligands podophyllotoxin and MTC competed with 1 for tubulin binding, suggesting that colchicine binding site was involved in the binding interaction. Silence et al. [17] used subsite-specific ligands to compete with 1 for tubulin binding and concluded that A-subsite but not $\mathrm{C}$-subsite of colchicine binding-site was occupied by 1 . In combination with other colchicine binding-site anti-microtubule agents, Ducki et al. [18] performed a 5D-QSAR study and concluded that the methyl substitution on the a-alkene position induced a significant change in the preferred conformation from s-cis to s-trans that favored tubulin binding, which potentially explained the higher potency observed with a-methyl chalcones. Similarly, a-methyl chalcone compound 2, designed by Ducki et al. [19], exhibited antimicrotubule activity biochemically and potent cytotoxicity in vitro through disrupting microtubule structure and inducing cell cycle arrest. Kim et al. [20] modeled the binding interaction of 1 with tubulin and found an adjacent unoccupied pocket, based on which compound 3 was designed. 3 exhibited micromolar potency for inhibiting tubulin polymerization and cancer cell growth but without significant improvement in potency. Alias et al. [21] isolated a cytotoxic chalcone 4 (pedicin) from Fissistigma lanuginosum, which inhibited tubulin polymerization biochemically with an IC50 of $300 \mu \mathrm{M}$. Lawrance et al. [22] synthesized six chalcones targeting anti-microtubule activity, four of which showed micromolar anti-microtubule potency in biochemical assays and sub-micromolar cytotoxicity against a panel of cancer cell lines with compound 5 being the most potent. Boumendjel et al. [23] and Martel-Frachet et al. [24] synthesized two closely related cytotoxic

*Corresponding author: Chengguo Xing, Department of Medicinal Chemistry, College of Pharmacy, University of Minnesota, 2231 6th St SE, Minneapolis, MN 55455, USA, Tel: 612-626-5675; E-mail: xingx009@umn.edu

Received July 22, 2015; Accepted August 20, 2015; Published August 22, 2015

Citation: Zhou B, Xing C (2015) Diverse Molecular Targets for Chalcones with Varied Bioactivities. Med chem 5: 388-404. doi: 10.4172/2161-0444.1000291

Copyright: $\odot 2015$ Zhou B, et al. This is an open-access article distributed under the terms of the Creative Commons Attribution License, which permits unrestricted use, distribution, and reproduction in any medium, provided the original author and source are credited. 
chalcones containing an indole moiety, 6 and 7, both of which inhibited tubulin polymerization biochemically and demonstrated in vivo anticancer activity in mouse xenograft models. In addition, 7 was able to compete off tubulin-bound colchicine, suggesting the involvement of colchicine-binding site in the binding interaction. Dyrager et al. [25] synthesized a series of dihalogenated chalcones and related dienones, and found compound 8 to be a microtubule stabilizer which fell in the same category as paclitaxel. Similarly, chalcones 9-14 were developed as anti-microtubule agents and showed cytotoxicity against tumor cell lines via cell cycle arrest [26-31]. In addition, compound 10 inhibited tumor cell migration [27], another microtubule-related activity, and compound 12-13 demonstrated in vivo antitumor activity in xenograft models [28,30]. Other anticancer pharmacophores have also been fused with the chalcone scaffold and yielded several novel anti-microtubule agents. Wang et al. [32,33] and Yang et al. [34] designed and synthesized a series of chalcones fused with a pyran ring to mimic cytotoxic natural product millepachine, among which compound 15 showed the best cytotoxicity towards a panel of cancer cells. Ruan et al. [35] designed compound 16 by incorporating a resveratrol moiety into chalcone scaffold, and Kamal et al. [36,37] designed compound 17 and 18 by incorporating either an amidobenzothiazole or a phenstatin moiety into chalcone core. All of these compounds were shown to be antimicrotubule agents that exhibited cytotoxicity against various cancer cell lines (Figure 2).

\section{Kinases}

Protein phosphorylation, catalyzed by over 500 kinases encoded by human genome, regulates most if not all aspects of cell life. Dysregulation of kinase activities is associated with a variety of disorders including cancer, inflammatory diseases, diabetes, infectious diseases, and cardiovascular diseases. Kinase inhibitors as potential therapeutics have thus attracted great research attention for decades, with more than 30 clinically approved drugs to date, and many more
A.

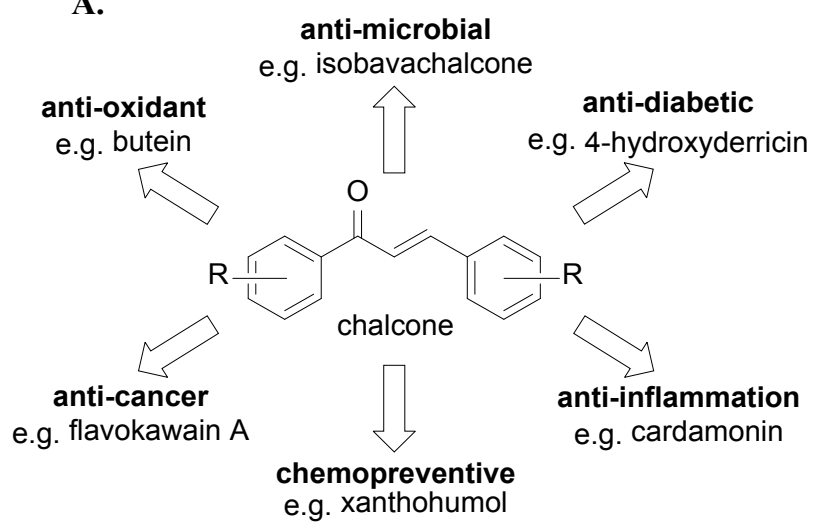

B.<smiles>COCCOCCOc1cc(OC)ccc1C(=O)/C=C/c1ccc(OC)cc1</smiles><smiles>CC(C)=CCOc1ccc(C=CC(=O)c2ccc(OCC=C(C)C)cc2OCC(=O)O)cc1</smiles>
antiulcer / mucoprotective

Figure 1: A. Structure scaffold of chalcone and examples of bioactivities; B. Examples of chalcones that have been marketed or clinically tested.

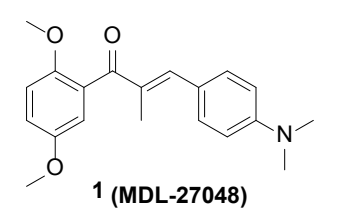<smiles>COc1ccc(/C=C(\C)C(=O)c2cc(OC)c(OC)c(OC)c2)cc1O</smiles><smiles>COc1c(O)c(OC)c(C(=O)/C=C/c2ccccc2)c(OC)c1OC</smiles><smiles>COc1cc(C(=O)/C=C/c2ccc3c(c2)OCCO3)cc(OC)c1OC</smiles><smiles>[R]C([Y])([R])[R]([H])([H])[H]</smiles><smiles>O=C(/C=C/C=C/c1cn(Cc2ccccc2)c2ccccc12)c1cc(Cl)cc(Br)c1O</smiles><smiles>Cc1ccc(C(=O)/C=C/c2cccc(Cl)c2Oc2c([N+](=O)[O-])cc(C(F)(F)F)cc2[N+](=O)[O-])cc1</smiles><smiles>COc1cc(C(=O)/C=C/c2ccc3ccccc3c2)cc(OC)c1OC</smiles>

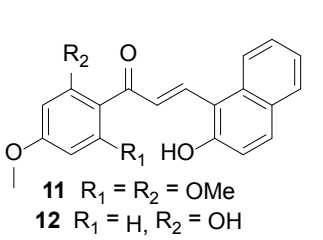<smiles>COc1ccc(/C=C/C(=O)c2ccccc2-c2cccc(F)c2)cc1O</smiles><smiles>COc1ccc(/C=C/C(=O)c2cc3c(cc2OC)OCS3)cc1</smiles><smiles>COc1ccc(/C=C/C(=O)c2ccc(OC)c3c2OC(C)(C)C=C3)cc1N</smiles>
15

10

$$
12 \mathrm{R}_{1}=\mathrm{H}, \mathrm{R}_{2}=\mathrm{OH}
$$$$
13
$$<smiles>COc1ccc(/C=C/C(=O)c2cc(OC)c(OC)c(OC)c2)cc1OCC(=O)Nc1nc2ccccc2s1</smiles><smiles>COc1ccc(C(=O)/C=C/c2cc(C(=O)c3cc(OC)c(OC)c(OC)c3)ccc2OC)cc1N</smiles>

18

Figure 2: Structures of anti-microtubule chalcones. 
in clinical trials [38-41]. Numerous literature reports have shown the potential of chalcones to regulate kinase activities through either direct enzymatic inhibition or altering kinase expression. Since this review focuses on chalcone's direct targets, we will only discuss those examples that reveal direct kinase inhibition.

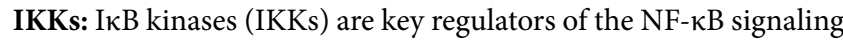
pathway, which plays an important role in cell response to various stimuli such as TNF, IL-1, UV radiation, stress, and pathogenic assaults. The activation of IKKs leads to phosphorylation and degradation of $\mathrm{I} \kappa \mathrm{B}$, and subsequently nuclear translocation of NF- $\kappa \mathrm{B}$ that initiates downstream transcription of target genes. Inhibiting IKKs is therefore considered a promising approach for intervening NF- $\kappa B$ related health conditions, especially cancer and inflammatory diseases $[42,43]$. Pandey et al. [44] found that anticancer and anti-inflammatory natural chalcone compound 19 (butein) directly inhibited IKK $\beta$ activity both biochemically and in cells, and subsequently reduced the downstream products of NF- $\mathrm{\kappa B}$ activation, resulting in elevated apoptosis induced by TNF and other chemotherapeutic agents. In addition, cysteine 179 in IKK $\beta$ was found to be crucial to this inhibition, suggesting that a covalent Michael-type interaction of 19 with IKK $\beta$ at this residue might be involved. Similar observations were made by Funakoshi-Tago et al. [45] and Harikumar et al. [46], where 20 (licochalcone A) and 21 (xanthohumol) directly inhibited IKK $\beta$ through the involvement of cysteine 179 residue as well. Synthetically, series of adamantyl chalcones were developed by Bayon et al. [47], Lorenzo et al. [48,49] and Garcia-Rodriguez et al. [50] as cytotoxic agents; many of them were found to inhibit IKKa and IKK $\beta$ both biochemically and in cells and the inhibitory activity correlated well with the in vitro cytotoxicity. Compound 22 was the most potent inhibitor among this series with low micromolar potency (Figure 3 ).

Aurora kinases: Aurora kinases are key regulators of mitosis whose aberrant expression is found in various types of cancer. Aurora A phosphorylates Polo like kinase 1 (PLK1) which then phosphorylates Cdc25C and Weel and subsequently activates cyclin B-CDK1 complexes to promote mitotic entry. Aurora B is critical for correct microtubulekinetochore attachments, the establishment of the spindle assembly checkpoint and cytokinesis. Both of them are therefore promising anticancer targets [51]. Limper et al. [52] studied natural products from Psoralea corilifolia and a geranyl chalcone 23 (xanthoangelol) was identified to inhibit both Aurora A and B kinases with micromolar potency and induce apoptotic cell death in cancer cell lines. Shin et al. [53] synthesized a library of chromenyl chalcones. Compound 24, demonstrating the most potent cytotoxicity against cancer cell lines and inhibition of colony formation, inhibited both Aurora A and B kinases with no effect on other kinases. Shin et al. [54] also synthesized a series of chalcones as cytotoxic compounds against ovarian cancer cells, where the most potent compound 25 was found to be an Aurora A inhibitor (Figure 4).

Receptor tyrosine kinases: Receptor tyrosine kinases (RTKs), such as VEGFR, EGFR, and FGFR, are cell signaling effectors that regulate normal development and homeostasis, whose aberrant activities are responsible for many pathological conditions, especially cancers. Many small molecule inhibitors of RTKs are clinical cancer therapies [55,56]. Aforementioned study by Limper et al. [52] found that the natural geranyl chalcone 23 (xanthoangelol) inhibited not only the Aurora kinases but also EGFR activity in enzymatic assays, which may contribute to its cytotoxicity. Yang et al. [57,58] showed that 19 (butein) was a micromolar inhibitor of EGFR and that this inhibition was competitive against ATP and non-competitive against the substrate, suggesting the ATP binding site being the potential binding pocket. Jung et al. [59] showed that the cytotoxic natural chalcone 26 (isoliquiritigenin) inhibited not only wild-type EGFR, but also a mutant type prevalent in non-small-cell lung cancer cells, in an ATP-competitive manner. Xenograft study revealed in vivo anticancer efficacy of isoliquiritigenin against cancer cells expressing mutant EGFR. The same compound was studied by Wang et al. [60] and inhibited VEGFR2 enzymatic activity and consequently inhibited endothelial cell growth and angiogenesis induced by VEGF in vivo. Lee et al. [61] found that the simple unsubstituted chalcone 27 inhibited VEGFR biochemically as well as tumor growth and angiogenesis in a xenograft model. Interestingly, many other RTKs besides VEGFR were also found to be inhibited by 27, such as EphB2, FGFR3, and MSPR (Figure 5).

Other kinases: Song et al. [62] studied the anti-inflammatory natural chalcone 20 (licochalcone A) and found that it suppressed UVinduced COX-2 expression, an important proinflammatory enzyme, through direct binding and inhibition of kinases PI3K, MEK1, and B-Raf. The binding study was performed with bead-immobilized compound and revealed that ATP competed the binding of 20 to PI3K and B-Raf, but not MEK1, suggesting different binding sites/modes with different kinases. Jing et al. [63] studied the cytotoxicity of natural<smiles>O=C(/C=C/c1ccc(O)c(O)c1)c1ccc(O)cc1O</smiles>

19 (butein)

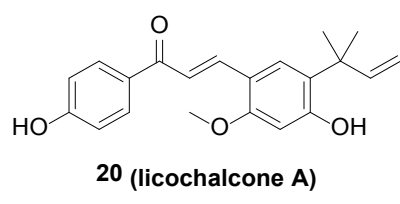

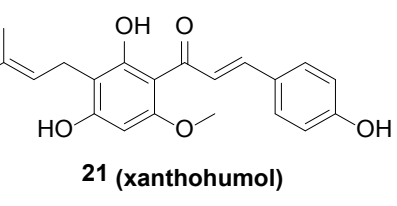

Figure 3: Structures of chalcones as IKK inhibitors

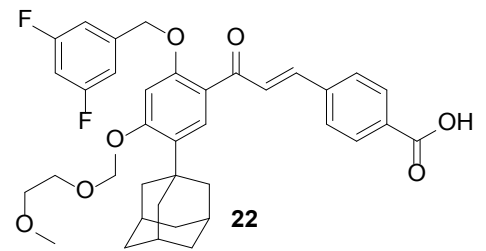<smiles>CC(C)=CCC/C(C)=C/Cc1c(O)ccc(C(=O)/C=C/c2ccc(O)cc2)c1O</smiles>

23 (xanthoangelol)<smiles>COc1ccc2c(c1)C=C(C(=O)/C=C/c1c(OC)cc(OC)cc1OC)CO2</smiles>

24

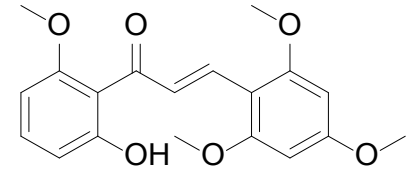

25

Figure 4: Structures of chalcones as Aurora kinase inhibitors. 
chalcone compound 28 (isobavachalcone) against various cancer cell lines, which was potentially attributed to its inhibitory activity against Akt, a key effector in the PI3K/Akt signaling pathway regulating cell proliferation and growth and hence a promising anticancer target. Wang et al. [64] studied the mechanisms by which 29 (broussochalcone A) attenuated respiratory burst in stimulated neutrophils and protein kinase $\mathrm{C}$ (PKC) was found to be directly inhibited by broussochalcone $\mathrm{A}$, and the interaction was shown to be at the catalytic domains (Figure 6).

\section{Oxidoreductases}

Cyclooxygenase and 5-lipoxygenase: Cyclooxygenase (COX) and 5-lipoxygenase (5-LOX) are key enzymes in the arachidonic acid (AA) metabolic pathway, whose end products are inflammatory mediators such as prostaglandins (PGs), leukotrienes (LTs), and thromboxanes (TXs) that are highly involved in the pathology of various inflammatory diseases and cancers. Therefore, COX and 5-LOX have long been considered potential therapeutic targets for these diseases $[65,66]$. The chalcone scaffold has been widely explored as a pharmacophore to inhibit COX and 5-LOX. Gerhauser et al. [67] found that natural chalcone 21 (xanthohumol) inhibited both isotypes of COX with higher potency against COX-1 than COX-2; however, no further biological relevance was reported. Sogawa et al. [68] synthesized a series of chalcones bearing 3,4-dihydroxy functional groups and many of them were potent 5-LOX inhibitors with nanomolar potency and moderate COX inhibitors with micromolar potency. Further in vivo anti-inflammation efficacy was evaluated using AA-induced mouse ear edema model, and the most potent compound 30 was among the most potent inhibitors of both enzymes in their library. Lin et al. [68] studied several natural chalcone products for their inhibitory activity against AA-induced platelet aggregation and identified 29 (broussochalcone A) as the most potent candidate, which was explained by its COX inhibitory activity. Lin et al. [69] further expanded the chalcone library as well as the anti-inflammatory scope, where compound 31 was identified as a COX inhibitor that potently inhibited AA- or adrenaline-induced platelet aggregation, compound 48/80-induced mast cell degranulation, and peptide fMLP-induced neutrophil activation. Herencia et al. [71] synthesized a series of 2-chloroquinolinyl chalcones and compound 32 was found to inhibit both 5-LOX and COX. In vivo study showed that it reduced the production of PGE2 and LTB4 by stimulated leukocytes. Araico et al. [72] developed a series of phenylsulphonyl urenyl chalcones as dual inhibitors of COX-2 and 5-LOX, and the most potent inhibitor 33 demonstrated potent reduction in PGE2 and LTB4 production in vitro. Zarghi et al. [73] designed a series of chalcones bearing a p-methylsulphonyl group as it frequently appears in the structure of COX-2 inhibitors, and the most potent inhibitor 34 showed a more than 100-fold selectivity towards COX-2 than COX-1 without further biological evaluation. Tran et al. [74] studied the inhibitory effect of 2'-hydroxychalcones on LPS-induced cell-based PGE2 production and the most potent compound 35 was docked into COX-2 binding pocket without further biochemical confirmation. El-Sabbagh et al. [75] incorporated an $\mathrm{N}$-arylpyrazole moiety, the major pharmacophore in celecoxib, into a bis-chalcone scaffold and obtained several selective COX-2 inhibitors with in vivo edema inhibition activity. Compound 36 was the most potent and selective inhibitor in this series, and its activity profile was comparable to that of celecoxib. Jantan et al. [76] studied synthetic chalcone derivatives and found compound 37 biochemically inhibited both isotypes of COX as well as 5-LOX. Wu et al. [77] studied several heterocyclic chalcones for their cell-based inhibitory activity against AA- and collagen-induced platelet aggregation and TXB2 formation, where the most potent compound 38 exhibited COX-1 enzymatic inhibition. Bukhari et al. [78] studied a series of naphthyl chalcone derivatives and found compound 39 as a non-selective COX inhibitor with micromolar potency. Finally, Ozdemir et al. [79] evaluated a series of indole-chalcones as COX inhibitors, among which the most potent inhibitor compound 40 showed in vivo antiinflammation activity (Figure 7).

Tyrosinase: Tyrosinase is the primary enzyme catalyzing the multi-step oxidation of tyrosine in the production of melanin, the skin pigment. Increased tyrosinase activity can cause various types of hyperpigmentation disorders, hence an optimal drug target for such conditions [80] Nerya et al. [81] investigated the tyrosinase inhibitory activity of licorice-derived natural products and identified 26 (isoliquiritigenin) as a tyrosinase inhibitor both biochemically and in melanocytes. Further studies by Nerya et al. [82] and Khatib et al. [83]<smiles>CC(C)=CCC/C(C)=C/Cc1c(O)ccc(C(=O)/C=C/c2ccc(O)cc2)c1O</smiles>

23 (xanthoangelol)<smiles>[R]c1cc(/C=C/C(=O)c2ccc(O)cc2O)ccc1O</smiles><smiles>O=C(/C=C/c1ccccc1)c1ccccc1</smiles>

27

Figure 5: Structures of chalcones as inhibitors of RTKs.<smiles>C=CC(C)(C)c1cc(/C=C/C(=O)c2ccc(O)cc2)c(OC)cc1O</smiles>

20 (licochalcone A)<smiles>[R]c1cc(/C=C/C(=O)c2ccc(O)c(CC=C(C)C)c2O)ccc1O</smiles>

\section{8 (isobavachalcone) $\mathrm{R}=\mathrm{H}$ 29 (broussochalcone A) $\mathrm{R}=\mathrm{OH}$}

Figure 6: Structures of chalcones as inhibitors of other kinases. 
identified 19 (butein) and a few other chalcones as tyrosinase inhibitors with comparable potency. Interestingly, 19 itself was found to be a substrate of tyrosinase and the o-quinone product was detected with LC-MS. Jun et al. [84] synthesized a series of 2',4',6'-trihydroxychalcones, among which compound 41 was the most potent tyrosinase inhibitor. Kinetic study revealed competitive inhibition of 41 against tyrosine as the substrate, giving insight into the potential binding site. Zhang et al. [85] studied the inhibitory effect of natural chalcone 42 on tyrosinase activity and melanin biosynthesis, and found that it competitively inhibited tyrosinase activity both biochemically and in cells. Seo et al. [86] evaluated several synthetic sulfonylamino chalcones for their anti-pigmentary effect biochemically and in cells, where compound 43 was demonstrated as the most potent inhibitor of melanin formation in cell-based experiment, although it wasn't the most potent in enzymatic assay. Part of its cellular activity may be attributed to reduced protein level of tyrosinase as revealed by Western analysis. Finally, compound 43 was demonstrated to inhibit UV-induced skin pigmentation in brown guinea pigs (Figure 8).

Sex hormone converting enzymes: Sex hormones as important signaling messengers play major roles in the functions of reproductive organs, and their dysregulation is highly associated with diseases such as breast cancer and prostate cancer $[87,88]$. Enzymes involved in the biosynthesis of sex hormones are thus potential drug targets for such diseases. Chalcones have shown the potential to inhibit some of these enzymes, such as aromatase involved in estrogen synthesis, and $5 \alpha$-reductase and $17 \beta$-hydroxysteroid dehydrogenase involved in androgen synthesis.

Aromatase: Wang et al. [89] screened five chalcones for aromatase inhibitory activity both biochemically and in MCF-7aro breast cancer cells. The most potent inhibitor 19 (butein) suppressed testosteroneinduced MCF-7aro cell growth, which was synergistically enhanced by co-treatment with estrogen receptor antagonist ICI-182780. Similarly, natural chalcone 21 (xanthohumol) was identified by Monteiro et al. [90] as an aromatase inhibitor in a cell-based assay, and its antiproliferative effect was reverted by addition of estradiol. Le Bail et al. [91] evaluated a series of natural and synthetic chalcones for aromatase inhibitory activity in biochemical assays, from which 44 (naringenin chalcone) was found to be the most potent inhibitor. Lee et al. [92] isolated twenty-two natural products from Broussonetia papyrifera and several potent aromatase inhibitors were identified with compound 45 of sub-micromolar potency.

5a-Reductase: Shimizu et al. [93] identified geranyl chalcone 46 as a natural inhibitor of $5 a$-reductase biochemically, where the geranyl group was found to be important for potency. Similarly, Hussein et al. [94] isolated a $\beta$-hydroxyl chalcone 47 as a natural inhibitor of $5 \alpha$-reductase in a cell-based assay.

17 $\beta$-Hydroxysteroid dehydrogenase: In the study by Le Bail et al. [91] mentioned above, in addition to aromatase inhibition, several chalcones also exhibited moderate inhibitory activity against $17 \beta$-hydroxysteroid dehydrogenase biochemically, among which 48 was the most potent. Cellular evidence of such interaction, however, is unavailable (Figure 9).

Aldose reductase: Aldose reductase (ALR2) catalyzes the conversion of glucose to sorbitol, the first step in polyol pathway of glucose metabolism. Increased flux of glucose through polyol pathway under conditions such as diabetes initiates a complex cascade leading to oxidative stress and inflammation, which renders ALR2 a promising drug target for intervention of inflammatory conditions, particularly the chronic complications associated with diabetes $[95,96]$. Investigation of chalcone compounds as ALR2 inhibitors started with the discovery by Aida et al. [97,98] that natural chalcones 26 (isoliquiritigenin) and 49 (isoliquiritin) potently inhibited ALR2 activity biochemically. In vivo<smiles>[Z10][C@H](O)[C@H](O)OC</smiles><smiles>CSc1ccc(C(=O)/C=C/c2ccc(C)cc2)cc1</smiles>

ó 'o 34<smiles>COc1cccc(/C=C/C(=O)c2ccccc2O)c1OC</smiles>

35<smiles>COc1ccc(OC)c(C(=O)/C=C/c2ccsc2)c1</smiles><smiles>COc1cc2ccccc2c(/C=C/C(=O)c2ccc3c(c2)OCCO3)c1OC</smiles><smiles>COc1ccc(OC)c(C(=O)/C=C/c2ccc(O)c(O)c2)c1</smiles>

30

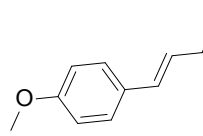

O 0<smiles>O=C(/C=C/c1ccc(F)cc1)c1cc2ccccc2cc1Cl</smiles><smiles>COc1cc(/C=C/C(=O)c2ccc(NC(=O)Nc3ccc(C)cc3)cc2)cc(OC)c1OC</smiles><smiles>COc1cc(OC)cc(C(=O)/C=C/c2ccc(CNCCO)cc2)c1</smiles>

36<smiles>N#Cc1ccc(C(=O)/C=C/c2c[nH]c3ccc(Br)cc23)cc1</smiles>

Figure 7: Structures of chalcones as COX inhibitors.<smiles>[R]c1cc(/C=C/C(=O)c2ccc(O)cc2O)ccc1O</smiles>

26 (isoliquiritigenin) $\mathrm{R}=\mathrm{H}$<smiles>O=C(/C=C/c1ccc(O)cc1O)c1c(O)cc(O)cc1O</smiles>

41<smiles>CC(C)=CCc1c(O)cc(O)c(C(=O)/C=C/c2ccc(O)cc2O)c1O</smiles>

42

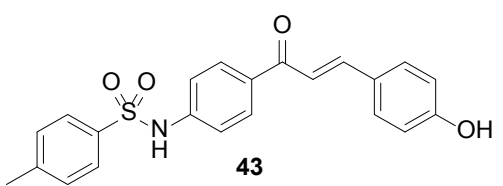

Figure 8: Structures of chalcones as tyrosinase inhibitors. 
study showed that 26 significantly inhibited sorbitol accumulation in red blood cells, sciatic nerves, and lenses in diabetic rats. Similarly, Jung et al. [99] isolated natural chalcone 50 (kuraridin) from Sophora flavescens which exhibited ALR2 inhibitory activity biochemically. Lim et al. [100] studied a panel of chalcones and found 19 (butein), an equally potent ALR2 inhibitor as 26 in enzymatic assays, exhibited better inhibitory activity against sorbitol accumulation in vivo. Rastelli et al. [101] modeled the interaction between 26 and ALR2, and studied the structural requirements, where they found each of the three hydroxyl groups to be essential. Severi et al. [102] and Lim et al. [103] synthesized analogs of 26 and obtained equally potent inhibitors 51 and 52 without further biological investigation. By introducing an additional hydroxyl group onto 26, Iwata et al. [104] obtained nanomolar inhibitor 53 which is about 100 -fold more potent than 26 (Figure 10).

Thioredoxin reductase: Thioredoxin system, consisting of thioredoxin reductase (TrxR), its substrate thioredoxin (Trx), and cofactor NADPH, is one of the major biological antioxidant systems and regulates various cellular processes. Overexpression of TrxR has been observed in many tumors, rendering it a potential target for chemotherapy [105,106]. Gan et al. [107] developed a panel of Michael acceptor-type pharmacophores for TrxR inhibition, among which chalcones (such as 54) and closely related 1,5-diphenyl-pent-1en-3-ones (DPPen) proved to inhibit cellular TrxR activity. The good correlation between TrxR inhibitory potency and cytotoxicity within their library indicated involvement of TrxR inhibition in their cytotoxic mechanisms. Interestingly, the covalent adduct of the most potent DPPen analog with TrxR at selenocysteine residue U498 was observed via MS analysis, giving insight into potential interaction modes of chalcones with TrxR. Zhang et al. [108] screened the cytotoxicity of forty-four synthetic chalcones against a panel of cancer cell lines, and the most potent compound 55 was tested for TrxR inhibition. Its inhibition of TrxR was selective over other oxidoreductases such as glutathione reductase and glutathione peroxidase, and U498 residue was involved in the interaction as much weaker inhibition was observed with U498C mutant. In cells, 55 significantly decreased cellular thiol level and increased ROS level as a result of TrxR inhibition. The cytotoxicity of 55 was attenuated by antioxidant $\mathrm{N}$-acetylcysteine, and enhanced by GSH synthesis inhibitor BSO, further supporting the important role of TrxR inhibition in the cytotoxic mechanism of 55. However, this could also be due to non-specific Michael addition with thiols, which deserves further clarification.

Monoamine oxidase: Monoamine oxidases (MAOs) are important metabolic enzymes catalyzing the oxidative degradation of monoamine neurotransmitters. Elevated activities of MAOs can lead to reduced cognitive ability and ROS accumulation, and is therefore associated with depression and neurodegenerative diseases, rendering MAOs important drug targets for such conditions [109]. Early study with natural products from Glycyrrhiza uralensis root by Tanaka et al. [110] identified several chalcones, such as compound 56, as competitive inhibitors of mitochondrial MAO from rat liver. Chimenti et al. [111] screened sixteen synthetic chalcones against MAO-A and MAO-B and most compounds showed inhibitory activity against MAO-B but not MAO-A, with potency ranging from low nanomolar to micromolar. The most potent compound 57 was four times more potent than clinically used MAO-B inhibitor selegiline and over 10,000-fold selective over MAO-A. The inhibition was irreversible as removing compound from enzyme did not result in recovery of enzymatic activity, suggesting potential covalent modification. Robinson et al. [112] synthesized a panel of furano-chalcones and they all showed competitive inhibition of MAO-B with micromolar potency but very weak or no inhibition of MAO-A. Interestingly, inhibition by the most potent compound 58 was reversible, contrary to the previous study. However, no further study was performed to investigate the potential contribution of MAO inhibition to chalcones' bioactivities (Figure 11).

\section{Hydrolases}

\section{Proteases:}

Cathepsins: Cathepsins are cysteine proteases mainly involved in the bulk protein degradation within lysosomes. Recent findings have shed light on their involvement in many pathological processes, including cancer, arthritis, and atherosclerosis. High cathepsins activity is associated with cancer progression, invasion, and metathesis, thus making them potential drug targets [113]. Kim et al. [114] evaluated a panel of synthetic chalcones for cytotoxicity and cathepsin inhibition; the most cytotoxic compound 59 was the most potent inhibitor of

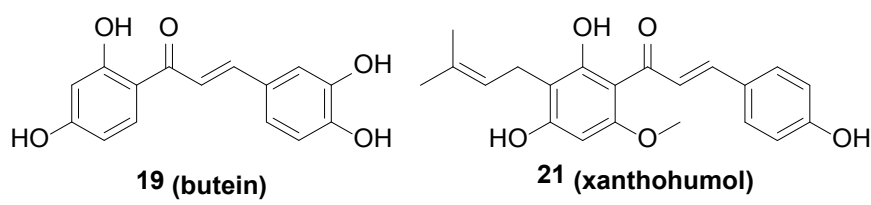

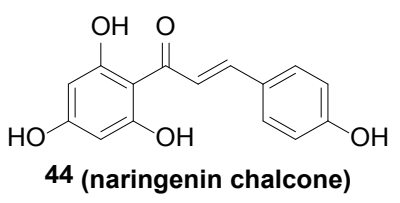<smiles>CC(C)=CCC/C(C)=C/Cc1c(O)ccc(C(=O)/C=C/c2ccc(O)c(O)c2)c1O</smiles><smiles>COc1cc(O)c(C(=O)/C=C(\O)c2ccc(O)cc2)c(O[Ga])c1</smiles><smiles>O=Cc1ccccc1</smiles><smiles>[Z15]c1ccc(O)cc1/C=C/C(=O)c1ccc(O)c(C/C=C(\C)COC(=O)/C=C/c2ccc(O)cc2)c1O</smiles>

Figure 9: Structures of chalcones as inhibitors of sex hormone converting enzymes.
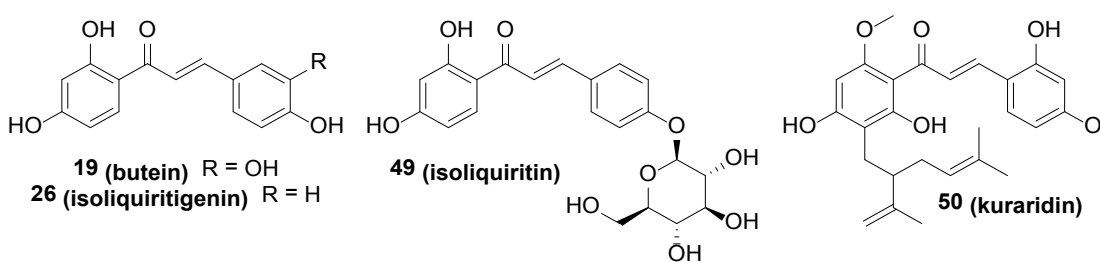<smiles>O=C(/C=C/c1cccs1)c1ccc(O)cc1O</smiles>

51

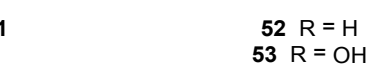

Figure 10: Structures of chalcones as ALR2 inhibitors. 
cathepsin B and L with micromolar potency. Similarly, Ramalho et al. [115] screened fifteen synthetic chalcones and cytotoxic compound 60 was found to inhibit cathepsin $\mathrm{K}$ while none of the compounds significantly inhibited cathepsin B. Raghav et al. [116] synthesized twenty-seven flavonoids and screened them for cathepsin $\mathrm{B}$ and $\mathrm{H}$ inhibitory activity, where 2'-hydroxychalcones showed better potency than flavones and flavanones bearing the same substituents, and 4-nitro substitution was found to possess the best potency. Compound 61 with both structural features was the most potent inhibitor within their library. The inhibition kinetics was also studied and revealed a competitive mode of inhibition, suggesting potential binding at the catalytic site.

$\beta$-Secretase: $\beta$-Secretase (BACE1) catalyzes the cleavage of $\beta$-amyloid precursor protein to produce neurotoxic peptide $\beta$-amyloid, whose aggregation is an important pathological hallmark for Alzheimer's disease (AD). Therefore, inhibiting BACE1 has become an attractive anti-AD strategy [117]. Ma et al. [118] screened natural products from cognition enhancing herb Glycyrrhiza uralensis for BACE1 inhibitory activity and identified 26 (isoliquiritigenin) as a moderate BACE1 inhibitor. In an attempt to improve potency, a 22 -membered library was constructed, from which compound 62 was identified as the most potent inhibitor with sub-micromolar potency. Similar potency was also achieve by Kang et al. [119], where compound 63 was identified from a series of sulfonamide chalcones as the most potent BACE1 inhibitor, with a reversible and mixed-type mode of inhibition. No further biological investigation was performed (Figure 12).

\section{Esterase:}

Histone deacetylases: Histone deacetylases (HDACs) are epigenetic enzymes catalyzing the deacetylation of histone, which regulates the transcription of various genes. Aberrant expression/ function of HDAC isoforms are involved in the pathology of many diseases, especially cancer, neurological diseases, and immune disorders [120, 121]. HDAC inhibitors and especially isoform-specific inhibitors are therefore potential drug candidates for these diseases.
Orlikova et al. [122] screened twenty-one natural chalcones for HDAC inhibitory activity. Only a few compounds showed moderate inhibitory activity against total cellular HDACs with 19 (butein) being the most potent. Zhou et al. [123] employed computational strategies based on structures and mechanisms of different isoforms of HDACs to design selective HDAC2 inhibitors, and identified $\beta$-hydroxymethyl chalcone 64 as a selective HDAC2 inhibitor over HDAC1 and HDAC3. Kahyo et al. [124] screened a panel of flavonoids for inhibition of the deacetylase activity of SIRT1, a class III HDAC whose substrates include tumor suppressor protein $\mathrm{p} 53$, thus a potential anticancer target. Chalcone 65 was identified to inhibit SIRT1 and as a consequence increase the acetylated p53 level in cells and inhibit cell proliferation (Figure 13).

Cholinesterases: Cholinesterases, including AChE and BChE, are esterases catalyzing the hydrolytic breakdown of neurotransmitter acetylcholine, and are hence involved in various neurological disorders, especially $\mathrm{AD}$. Inhibitors of cholinesterases have been widely used in clinic for symptomatic treatment of $\mathrm{AD}[125,126]$. The study performed by Kang et al. [119] as mentioned above with sulfonamide chalcones identified compound 63 not only as a potent BACE1 inhibitor, but also a moderate $\mathrm{AChE} / \mathrm{BChE}$ inhibitor, further indicating its potential anti-AD effect. Ansari et al. [127] identified compound 66 from twenty-four synthetic chalcones as an $\mathrm{AChE} / \mathrm{BChE}$ inhibitor with micromolar potency. Starting from 4-hydroxychalcone and guided by computational docking, Liu et al. [128] installed a tertiary amine substituent to form a cation- $\pi$ interaction with tryptophan 84 residue and obtained compound 67 which was $>100$-fold more potent in AChE inhibition than the parent compound and also inhibited BChE. Kinetic study revealed it as a mixed-type inhibitor of both enzymes. Further study by Liu et al. [129] suggested that introduction of a fluorine atom resulted in enhanced potency, where the most potent compound 68 was 20 -fold more potent than 67 . However, no further biological study was performed (Figure 14)

Protein tyrosine phosphatases: Protein tyrosine phosphatases (PTPs) catalyze the hydrolytic dephosphorylation of phosphotyrosine<smiles>COc1ccc(OC)c(C(=O)/C=C/c2cccc([N+](=O)[O-])c2)c1OC</smiles>

Figure 11: Structures of chalcones as TrxR and MAO inhibitors.<smiles>O=C(/C=C/c1ccc(O)cc1)c1ccc(O)cc1O</smiles>

26 (isoliquiritigenin)<smiles>O=C(/C=C/c1ccc(N2CCCC2)cc1)c1ccc(O)cc1</smiles>

59<smiles>O=C(/C=C/c1cccc(O)c1O)c1ccc(O)cc1O</smiles>

62<smiles>[R6]C=CCO</smiles><smiles>COc1ccc(/C=C/C(=O)c2ccccc2)cc1</smiles>

60<smiles>O=C(/C=C/c1ccc([N+](=O)[O-])cc1)c1ccccc1O</smiles>

61<smiles>Cc1ccc(S(=O)(=O)Nc2ccc(C(=O)/C=C/c3ccc(O)c(O)c3)cc2)cc1</smiles>

Figure 12: Structures of chalcones as inhibitors of proteases. 
residues of various protein substrates. Chalcones have shown potential interaction with at least two members of this enzyme family, namely PTP1B and CDC25B. PTP1B dephosphorylates and thereby inactivates insulin receptor kinase, and as a result elevated PTP1B activity is highly associated with decreased insulin sensitivity leading to diabetes and obesity [130]. CDC25B, on the other hand, is a mitotic regulator by dephosphorylating cyclin dependent kinases (CDKs) whose activity is essential for the G2/M transition in human cells, and thus a potential anticancer target [131]. Chen et al. [132] identified five natural products from Broussonetia papyrifera, including 29 (broussochalcone A), as moderate PTP1B inhibitors. Similarly, Yoon et al. [133] identified 21 (licochalcone A) from Glycyrrhiza inflata as a moderate PTP1B inhibitor, and through semisynthetic derivatization compound 69 was obtained with 2 -fold improved potency than that of 21 . Li et al. [134] isolated twenty-two natural products, ten of which are chalcones, from Angelica keiskei and screened them for PTP1B inhibitory activity, where compound 70 showed sub-micromolar potency of inhibition in a competitive manner. Zhang et al. [135] evaluated nineteen 2'-hydroxy4'-isoprenyloxychalcones for CDC25B inhibition, where compound 71 was identified as the most potent analog. Sun et al. [136] synthesized twenty-one 2',4',6'-trihydroxychalcones and identified compound 72 as a sub-micromolar inhibitor of both PTP1B and CDC25B in a competitive manner. Similarly, Xie et al. [137] identified compound 73 from eleven 2',4'-dihydroxychalcones as an inhibitor of both CDC25B and PTP1B. 73 also exhibited micromolar inhibitory activity against cancer cell proliferation as well as in vivo tumor growth inhibition, which might be associated with CDC25B inhibition (Figure 15).

Secreted phospholipase A2: Secreted phospholipases A2 (sPLA2) are extracellular enzymes catalyzing the hydrolytic release of fatty acids, including inflammatory intermediate arachidonic acid. Given its important role in inflammation as the enzyme catalyzing the first step of the arachidonic pathway, sPLA2 has long been considered a promising target for treatment of many inflammation-related diseases [138]. Two studies mentioned above by Jantan et al. [76] and Bukhari et al. [78] identified not only synthetic chalcones as COX inhibitors, but also moderate sPLA2 inhibitors such as compounds 74 and 75 . In addition, chalcone 76 was identified by Ballesteros et al. [139] as a sPLA2 inhibitor with cell-based anti-inflammatory activity where it inhibited LTB4, TXB2, and elastase production by stimulated neutrophils (Figure 16A).

a-Glucosidase: $\boldsymbol{\alpha}$-Glucosidase is an intestinal enzyme to release a-glucose from dietary polysaccharide for glucose absorption, and hence a valid anti-diabetic target on which commercial drugs such as acarbose and miglitol act [140]. Chalcones have been shown to possess potential inhibitory activity against $\alpha$-glucosidase. Natural chalcone 19 (xanthohumol) was shown by Liu et al. [141] to exhibit moderate a-glucosidase inhibitory activity in a non-competitive manner. Interestingly, the interaction with xanthohumol resulted in quenched intrinsic fluorescence, reduced hydrophobicity, and changes in $\mathrm{CD}$<smiles>O=C(/C=C/c1ccc(O)c(O)c1)c1ccc(O)cc1O</smiles>
19 (butein)<smiles>O=C(/C=C(\CO)c1ccccc1)c1ccccc1</smiles>

64<smiles>O=C(/C=C/c1cccc(O)c1)c1ccc(O)c(O)c1O</smiles>

65

Figure 13: Structures of chalcones as HDAC inhibitors.<smiles>Cc1ccc(S(=O)(=O)Nc2ccc(C(=O)/C=C/c3ccc(O)c(O)c3)cc2)cc1</smiles><smiles>O=C(/C=C/c1ccccc1O)c1ccccc1O</smiles>

66<smiles>CN(C)CCOc1ccc(C(=O)/C=C/c2ccccc2)cc1</smiles>

67<smiles>O=C(/C=C/c1ccc(F)cc1)c1ccc(OCCN2CCCC2)cc1</smiles>

68

Figure 14: Structures of chalcones as $A C h E / B C h E$ inhibitors.<smiles>CC(C)=CCc1c(O)ccc(C(=O)/C=C/c2ccc(O)c(O)c2)c1O</smiles>

29 (broussochalcone A)<smiles>CC(C)=CCOc1ccc(C(=O)/C=C/c2ccc(Cl)cc2)c(O)c1</smiles>

71<smiles>[R]c1ccc(C(=O)/C=C/c2cc(C(C)(C)C=C)c(O)cc2OC)cc1</smiles>

20 (licochalcone A) $\mathrm{R}=\mathrm{OH}$ $69 \mathrm{R}=\mathrm{OMe}$<smiles>COc1cc(/C=C/C(=O)c2ccc(O)cc2O)ccc1O</smiles>

72<smiles>C=C(C)C(=O)Cc1c(OC)ccc(C(=O)/C=C/c2ccc(O)cc2)c1O</smiles>

70<smiles>O=C(/C=C/c1ccccc1Br)c1ccc(O)cc1O</smiles>

73

Figure 15: Structures of chalcones as PTP inhibitors. 
spectrum of $\alpha$-glucosidase, all of which suggested a conformational change that may explain its non-competitive inhibition. Another natural chalcone 50 (kuraridin) was identified by Kim et al. [142] among a panel of flavonoids from Sophora flavescens as a moderate non-competitive inhibitor of a-glucosidase. Synthetically, Seo et al. [143] found that introduction of a sulfonamide substituent significantly increased chalcones' inhibitory activity against $\alpha$-glucosidase, and compound 63 which showed BACE1 and AChE/BChE inhibitory activity as mentioned above was also the most potent chalcone a-glucosidase inhibitor with sub-micromolar potency. Similarly, the study by Ansari et al. [127] mentioned above also identified chalcones as moderate inhibitors of a-glucosidase and 77 showed the best potency. Chinthala et al. [144] developed a series of chalcone triazoles as potential $\alpha$-glucosidase inhibitors, but the most potent compound 78 only showed mid-micromolar potency (Figure 16B).

\section{Microbial enzymes for antimicrobial activity}

Quite a number of chalcone compounds have shown antimicrobial activity against a spectrum of pathogens including bacteria, fungi, parasites, and viruses $[1,3]$. Various potential direct molecular targets have been suggested to account for such activities. Chiaradia et al. [145,146] and Mascarello et al. [147] discovered chalcone inhibitors of the bacterial enzymes MtbPtpA and MtbPtpB, which are protein tyrosine phosphatases secreted by Mycobacterium tuberculosis into host cells that attenuate host immune defenses. Compound 79 was identified as the most potent MtbPtpA inhibitor, whereas compound 80 was the most potent inhibitor of MtbPtpB. However, no data for their anti-tuberculosis activity is available. Another bacterial tyrosine phosphatase critical for Yersinia pathogenesis, YopH, was found to be inhibited by several synthetic chalcones [148] with compound 81 being the most potent inhibitor. Deng et al. [149] screened an NCI antiviral compound library for HIV-1 integrase inhibitory activity and identified compound 82 as the most potent inhibitor with in vitro anti-HIV activity. Sharma et al. [150] synthesized a chalcone library incorporating a 3-keto salicylic acid moiety targeting HIV-1 integrase, where compound 83 was identified as the most potent inhibitor with a higher in vitro anti-HIV potency than 82. Geyer et al. [151] discovered compound 84 as a potent inhibitor of Pfmrk, a cyclin-dependent kinase critical for the cell cycle of Plasmodium falciparum and thus an attractive target for malaria. However, the weak correlation between antimalarial activity and Pfmrk inhibition suggests the potential involvement of other mechanisms. Battenberg et al. [152] employed a chemical probe approach to study the antibacterial target of the natural product 4-hydroxyderricin. Probe 85 showed similar antibacterial activity as 4-hydroxyderricin. In subsequent target profiling experiment, it covalently pulled out seryl-tRNA synthase (STS) from the lysate of $S$. aureus, suggesting STS as the direct target of 85, which was confirmed by enzymatic inhibition assay. These results overall provided compelling evidence that STS is the direct target responsible for its antibacterial activity. Similarly, Wallock-Richards et al. [153] identified the simple unsubstituted chalcone 27 as a covalent inhibitor of Sortase A (SrtA), a bacterial transpeptidase involved in host cell attachment. The covalent labeling of SrtA by chalcone was revealed by mass spectrometry and confirmed with biochemical enzymatic inhibition assay. Abdullah et al. [154] introduced a quinoline moiety onto chalcone scaffold and identified compound 86 from a quinolone-chalcone library as the most potent inhibitor of bacterial DNA gyrase, which correlated well with its antibacterial activity tested against several strains of bacteria (Figure 17).

\section{Receptors}

Retinoic acid receptors: Retinoic acid receptors (RARs) are nuclear receptors that function as ligand-dependent transcription factors and thereby play important roles in various physiological as<smiles>Cc1ccc(C(=O)/C=C/c2ccc(CNCCO)cc2)o1</smiles>

74<smiles>COc1c(O)cc2ccccc2c1/C=C/C(=O)c1cc2ccccc2o1</smiles>

75<smiles>COc1ccc(/C=C/C(=O)c2ccc(OC)c(OC)c2O)cc1OC</smiles>

76

Figure 16A: Structures of chalcones as SPLA2 inhibitors.<smiles>C=C(C)C(CC=C(C)C)Cc1c(O)cc(OC)c(C(=O)C=Cc2ccc(O)cc2O)c1O</smiles><smiles>O=C(/C=C/c1ccccc1O)c1ccccc1</smiles>

77<smiles>COc1cc(O)c(CC=C(C)C)c(O)c1C(=O)/C=C/c1ccc(O)cc1</smiles>

19 (xanthohumol)

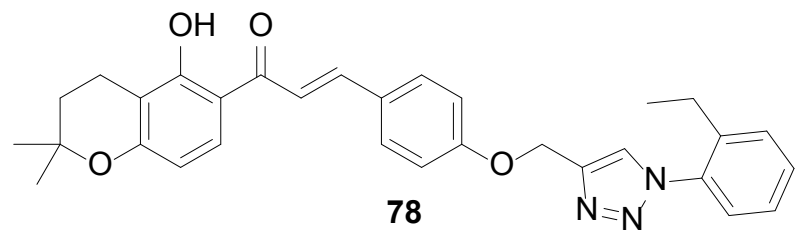

Figure 16B: Structures of chalcones as a-glucosidase inhibitors. 
well as pathological processes including cancer and inflammation [155]. Although much cell-based evidence exists in literature for chalcone's potential effect on RAR activity, these results were typically obtained from classical luciferase-based assays which could be due to a combination of effects on transcription-regulated protein level changes or post-translational modifications, and will not be discussed given the scope of this review. Nevertheless, evidence does exist that chalcones may directly interact with RARs. Kagechika et al. [156] synthesized a panel of carboxyl-containing chalcones and flavonoids, among which 87 and 88 were identified as potential RAR agonists that exhibited retinoidal effect - inducing differentiation in HL60 cells. These compounds were later confirmed to directly bind to all three isoforms of RARs with sub-nanomolar affinity [157,158]. Importantly, Klaholz et al. [158] obtained the co-crystal of 88 with the ligand binding domain of RAR $\gamma$, and the crystal structure clearly showed direct interaction of 88 with RARs in the ligand binding pocket.

Estrogen receptor Estrogen receptors (ERs) are sex hormone receptors acting as transcription factors upon interaction with ligands such as $17 \beta$-estradiol. Aberrant ER activity is associated with various pathologies including cancer, menopausal syndrome, inflammatory diseases, and others [159]. Tamir et al. [160] screened a panel of natural products from licorice root for estrogenic activity, where 26 (isoliquiritigenin) was found to promote growth of ER positive breast cancer cells T-47D at low concentration whereas at high concentration ER-independent cytotoxicity was observed. Direct binding to ER was studied based on competition with radio labeled ligand $17 \beta$-estradiol and 26 revealed low micromolar affinity. This is in agreement with the results obtained by Hajirahimkhan et al. [161] who also confirmed the induction of ER-responsive Tff1 mRNA upon treatment of 26. Similarly, Hegazy et al. [162] isolated several natural products from Tephrosia candida and identified 89 (candidachalcone) as a ER ligand with midmicromolar affinity, although no efficacy data was given.

Other receptors: Compound 26 (isoliquiritigenin) has also been identified as a positive allosteric modulator of GABA receptor by Cho et al. [163], and a histamine $\mathrm{H} 2$ receptor antagonist by Kim et al. [164], potentially explaining its neurological and gastric protective effects. Vazquez-Rodriguez et al. [165] synthesized a panel of coumarin chalcones as potential ligands of adenosine receptors where compound 90 was shown to bind to $A_{1}, A_{2 A}$, and $A_{3}$ receptors with micromolar potency. Unfortunately, no efficacy data were available. Balsera et al. [166] screened a library of natural products and identified 26 (isoliquiritigenin) as a positive allosteric modulator of $\alpha_{7}$ nicotinic acetylcholine receptor, based on which a panel of chalcones were synthesized and 91 was identified as the most potent compound with in vitro neuroprotective effect and in vivo analgesic and cognitive enhancing effect (Figure 18).

\section{Other proteins}

ABC transporters: ATP-binding cassette (ABC) transporters, such as p-glycoprotein (P-gp) and breast cancer resistant protein (BCRP), are a group of efflux pumps capable of transporting drugs out of the cells, whose overexpression are critical in conferring multi-drug resistance (MDR) in many cancer cell lines [167]. Han et al. [168] synthesized seventeen chalcones, most of which including compound<smiles>O=C(/C=C/c1ccccc1)c1ccccc1</smiles>

27 (chalcone)<smiles>COc1ccc(C(=O)/C=C/c2ccc(OCc3ccccc3)c(OC)c2)c(OC)c1</smiles><smiles>O=C(O)c1ccc(/C=C/C(=O)c2ccc3ccccc3c2)cc1</smiles><smiles>O=C(/C=C/c1ccc2c(c1)OCO2)c1cccc([N+](=O)[O-])c1</smiles><smiles>COc1cccc(/C=C/C(=O)c2ccccc2)c1O</smiles><smiles>O=C(O)c1cc(Br)cc(C(=O)/C=C/c2c(Cl)ccc(Cl)c2Cl)c1O</smiles><smiles>COc1ccc(C(=O)/C=C/c2cccc3ccccc23)c(OC)c1</smiles><smiles>C#Cc1cc(/C=C/C(=O)c2ccc(OC)c(CC=C(C)C)c2O)ccc1O</smiles><smiles>Cc1nc2c(C)c(Cl)ccc2cc1C(=O)/C=C/c1ccc(Br)cc1</smiles>

Figure 17: Structures of chalcone compounds targeting microbial enzymes.<smiles>O=C(/C=C/c1ccc(O)cc1)c1ccc(O)cc1O</smiles>

26 (isoliquiritigenin)<smiles></smiles>

89 (candidachalcone)<smiles>CC(C)(C)c1cc(C(=O)/C=C/c2ccc(C(=O)O)cc2)cc(C(C)(C)C)c1</smiles><smiles>CC1(C)CCC(C)(C)c2cc(C(=O)/C=C/c3ccc(C(=O)O)cc3)ccc21</smiles>

88<smiles>O=C(/C=C/c1ccc(O)cc1O)c1cc(O)ccc1O</smiles>

91

Figure 18: Structures of chalcone compounds as ligands of various receptors. 
92 showed BCRP inhibitory activity, increased cellular accumulation of mitoxantrone and sensitized resistant cells to mitoxantrone. None of the chalcones inhibited the ATPase activity of BCRP, suggesting a different interaction mode from canonical ABC inhibitors. Rangel et al. [169] screened fifty-four synthetic chalcones for BCRP inhibition by monitoring cellular mitoxantrone accumulation, and one of the most potent compounds 93 was non-cytotoxic itself but able to sensitize resistant cells to mitoxantrone to a level comparable to the sensitive cells. Similarly, Winter et al. [170] constructed a library of symmetric bis-chalcones and tested their BCRP inhibitory activity with the same method, where activity from zero to complete inhibition was observed with $5 \mu \mathrm{M}$ of chalcones, demonstrating a sharp SAR relationship. The most potent compound 94 completely sensitized resistant cells to mitoxantrone at sub-micromolar concentration. Mechanistically, 94 alone slightly stimulated basal ATPase activity of BCRP, but completely inhibited the substrate-induced ATPase activity increase. Canonical BCRP inhibitors through ATPase inhibition significantly synergized with 94 , suggesting a non-classical binding interaction of chalcones with BCRP, which is consistent with the aforementioned study. Liu et al. [171] synthesized twenty-five structurally diverse chalcones and evaluated their inhibitory effect against both P-gp and BCRP using resistant cells specifically expressing either form. Selective inhibitors were found where compound 95 potently inhibited P-gp but not BCRP and 96 selectively inhibited BCRP over P-gp. Gu et al. [172, 173] designed a panel of bifendate-chalcone hybrid as potential P-gp and BCRP dual inhibitors. The most potent compound 97 inhibited P-gp and BCRP mediated efflux and sensitized resistant cells to adriamycin and mitoxantrone without showing cytotoxicity by itself or inhibiting the ATPase activity of P-gp. The sharp SAR was explored by Parveen et al. [174] with a 3D-QSAR model that gave some structural insight into such interactions (Figure 19).

Topoisomerases: Topoisomerases (TOPOs), including TOPO-I and TOPO-II, are enzymes regulating the winding and unwinding of DNA, a critical process for DNA transcription and replication. Therefore, TOPO inhibitors have been widely used as anticancer and antibacterial agents
[175]. Several chalcones have shown TOPO inhibitory activity. The aforementioned study by Kim et al. [114] not only identified cytotoxic chalcone 59 as a cathepsin inhibitor, but also a nonselective TOPO-I/ II inhibitor with comparable potency as camptothecin and etoposide. However, the contribution of such inhibition to cytotoxicity was not studied. Akihisa et al. [176] studied the cytotoxicity of compounds isolated from Angelica keiskei against various cancer cells and the most potent compound 98 (4-hydroxyderricin) were found to inhibit TOPO-II more potently than etoposide, a clinically used anticancer drug acting as a TOPO-II inhibitor. Na et al. [177] obtained several chalcones with selective TOPO-II inhibitory activity over TOPO-I, and the most potent inhibitor 99 also demonstrated the highest cytotoxicity towards a panel of cancer cell lines (Figure 20).

MD-2: MD-2 is a small secreted glycoprotein that binds to both Toll-like receptor 4 (TLR4) and LPS, and thereby mediates LPSinduced TLR4 activation which triggers signal transductions related to inflammatory responses [178]. Chalcone compound 100 was identified by Roh et al. [179] via high-throughput screening as an inhibitor of LPS-induced inflammation and mechanistically as a MD-2 ligand. Such binding interaction antagonized LPS binding to MD-2 and led to inhibition of LPS-induced NF- $\kappa$ B activation in cells. Similarly, Wang et al. [180] investigated the anti-inflammatory mechanisms of compound 101 , and found that it bound to MD-2 and antagonized the binding of LPS in biochemical assays. In cells, 101 inhibited LPS-induced MAPK phosphorylation, NF- $\mathrm{KB}$ activation, and cytokine expression. In vivo, 101 enhanced survival and reduced lung injury in LPS-induce septic mice. Moreover, arginine 90 and tyrosine 102 were found to be crucial residues as mutation of either of them abolished the binding of 101 to $\mathrm{MD}-2$, giving insight into its potential binding site.

MDM2: As one of the mechanisms by which cancer cells evade apoptosis, overexpression of the oncoprotein MDM2 inhibits tumor suppressor protein p53 by binding to its transactivation domain and thus prevents p53-induced apoptosis of defective cells. Disruption of the interaction between MDM2 and p53 has thus become an interesting<smiles>COc1cc(/C=C/C(=O)c2ccc3ccccc3c2)ccc1OCc1ccccc1</smiles><smiles>COc1cccc(OC)c1/C=C/C(=O)c1ccc(C=O)cc1</smiles><smiles>COc1cc(OC)c(C2CCN(C)CC2)cc1C(=O)/C=C/c1ccccc1Cl</smiles>

95<smiles>COc1ccc(C(=O)/C=C/c2ccc(Cl)cc2)c(OC)c1</smiles>

96<smiles>COc1cccc(OC)c1/C=C/C=O</smiles>

l<smiles>COC(=O)/C=C(/C(=O)OC)c1c(/C=C/C(=O)c2cc(C)ccc2C)cc(OC)c2c1OCO2</smiles>

Figure 19: Structures of chalcones as inhibitors of $A B C$ transporters.<smiles>O=C(/C=C/c1ccc(N2CCCC2)cc1)c1ccc(O)cc1</smiles><smiles>COc1ccc(C(=O)/C=C/c2ccc(O)cc2)c(O)c1CC=C(C)C</smiles>

98 (4-hydroxyderricin)<smiles>COc1ccc(/C=C/C(=O)c2ccc(OCC3CS3)cc2OCC2CS2)cc1</smiles>

Figure 20: Structures of chalcones as TOPO inhibitors. 
Citation: Zhou B, Xing C (2015) Diverse Molecular Targets for Chalcones with Varied Bioactivities. Med chem 5: 388-404. doi: 10.4172/21610444.1000291

approach to combat cancer. Stoll et al. [181] studied the potential of chalcones to disrupt the MDM2/p53 interaction with ELISA and NMR methods, both of which identified compound 102 as the most potent inhibitor of this interaction through binding to MDM2. Resolution of individual residue signals with 2D NMR gave insight into the binding site, which was characterized as the tryptophan pocket defined by $\mathrm{S} 92$, V93, L54, G58, Y60, V93, and F91. However, no further biological study was performed to confirm this activity in cells.

Cholesteryl ester transfer protein: Cholesteryl ester transfer protein (CETP) is a transporter protein shuttling triglycerides and cholesteryl esters among lipoproteins VLDL, LDL, and HDL; it therefore plays important regulatory roles in lipid metabolism. Modulation of CETP activity is considered a promising strategy to reduce cardiovascular risks [182]. Hirata et al. [183] screened for CETP inhibitory activity from various plant extractions. From the most potent extraction, 21 (xanthohumol) was identified as the major component responsible for this inhibition as a non-competitive inhibitor with mid-micromolar potency. Further SAR study revealed the requirement of the prenyl substituent for potency and identified 103 (desmethylxanthohumol) as a slightly more potent CETP inhibitor (Figure 21).

\section{Discussion}

The diverse bioactivities and target profiles of chalcones is envisioned to be a double-edged sword. On one hand, it gives great opportunities to explore this simple pharmacophore for various target interactions, making it a privileged structure in drug design [184]. On the other hand, it presents the challenge of promiscuity, or poor selectivity, in their biological interactions. Other than in a limited cases where multiple target interactions are synergistic and therapeutically advantageous, such as COX-2/5-LOX dual inhibitors for antiinflammation [66] and AChE/BACE1 dual inhibitors for anti-AD [185], these multiple-target phenomena would potentially lead to offtarget interactions and hence unwanted side effects and compromised potency. The potential promiscuity may explain at least partly why there has been limited clinical success with chalcones in spite of its widespread research interest. Therefore, it is of great importance to identify the direct molecular targets responsible for these bioactivities, and ideally characterize their interaction modes, so their target profile can be fine-tuned to achieve better selectivity and potency. As reviewed above, there have been a wide variety of proteins identified as potential direct targets of chalcones, with many chalcone compounds implicated in<smiles>CC(C)CCOc1cccc(O)c1C(=O)/C=C/c1ccc(O)cc1</smiles>
100<smiles>COc1ccc(C(=O)/C=C/c2cccc(OC)c2OC)cc1</smiles>

101<smiles>O=C(O)COc1ccc(/C=C/C(=O)c2ccc(Cl)c(Cl)c2)cc1</smiles>
$\mathrm{I}^{\mathrm{OH}}$

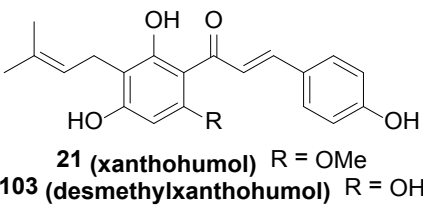

103 (desmethylxanthohumol) $\mathrm{R}=\mathrm{OH}$

Figure 21: Structures of chalcones acting as MD-2 or MDM2 ligands, or CETP inhibitors

\begin{tabular}{|c|c|c|}
\hline Compound & Potential direct target & Potential bioactivity relevance \\
\hline \multirow[t]{8}{*}{ Isoliquiritigenin } & EGFR & Anticancer \\
\hline & tyrosinase & Anti-pigmentation \\
\hline & ALR2 & Anti-diabetic, Anti-inflammation \\
\hline & BACE1 & Anti-AD \\
\hline & ER & Growth Promotion \\
\hline & $\mathrm{GABA}_{\mathrm{A}}$ receptor & Anxiolytic/Sedative \\
\hline & $\mathrm{H}_{2}$ receptor & Gastric Protection \\
\hline & $\alpha 7-n A C h R$ & Analgesic, Cognitive Enhancing \\
\hline \multirow[t]{6}{*}{ Butein } & IKK $\beta$ & Anticancer, Anti-inflammation \\
\hline & EGFR & Anticancer \\
\hline & tyrosinase & Anti-pigmentation \\
\hline & aromatase & Anticancer \\
\hline & ALR2 & Anti-diabetic, Anti-inflammation \\
\hline & HDAC & Anticancer \\
\hline \multirow[t]{5}{*}{ Xanthohumol } & IKK $\beta$ & Anticancer, Anti-inflammation \\
\hline & $\operatorname{cox}$ & Anti-inflammation \\
\hline & aromatase & Anticancer \\
\hline & a-glucosidase & Anti-diabetic \\
\hline & CETP & Anti-dyslipidemia \\
\hline \multirow[t]{3}{*}{ Licochalcone A } & IKK $\beta$ & Anticancer, Anti-inflammation \\
\hline & PI3K, B-Raf, MEK1 & Anti-inflammation \\
\hline & PTP1B & Anti-diabetic \\
\hline \multirow[t]{3}{*}{ Broussochalcone A } & PKC & Anti-inflammation \\
\hline & $\operatorname{cox}$ & Anti-inflammation \\
\hline & PTP1B & Anti-diabetic \\
\hline \multirow[t]{2}{*}{ Kuraridin } & ALR2 & Anti-diabetic, Anti-inflammation \\
\hline & a-glucosidase & Anti-diabetic \\
\hline \multirow[t]{2}{*}{ Xanthoangelol } & Aurora kinases & Anticancer \\
\hline & EGFR & Anticancer \\
\hline
\end{tabular}

Table 1: Examples of multi-targeting chalcones and potential relevance to their diverse bioactivities. 
multiple target interactions (Table 1). Such multi-target profile not only suggests promiscuity of the chalcone template, but also complicates the determination of contribution from each individual target to the overall bioactivity. For example, many targets reviewed here are potentially responsible for chalcones' cytotoxicity, such as microtubule, Aurora kinases, TrxR, HDACs, and TOPOs, but knowledge of their relative contributions for a given chalcone compound is largely lacking. Those targets showing sharp SAR, such as microtubule and BCRP, are thus of greater interest than those with flat SAR such as 5-LOX and cathepsins, because sharp SAR typically indicates specific binding modes which may be fine-tuned to achieve improved potency and better selectivity.

Special caution is needed when interpreting different levels of evidence for direct target interactions. With in vivo or cell-based studies, an observed effect for a target could be due to altered protein level, post-translational modification, direct interaction with compound, or their combinations. For this reason, in vitro or in vivo evidence alone, without direct biochemical confirmation, is premature to suggest a direct target interaction. On the other hand, although biochemical assays, including X-ray co-crystal structures, provide evidence for direct target interaction, there isn't a necessary connection to its biological activities without some in vitro or in vivo experiments, as the compound may preferentially interact with other targets. The result is therefore most convincing when the biochemical studies matches the in vitro and in vivo activities, which is the case with some of the studies reviewed here, such as some of the anti-microtubule, RTK inhibitory, and ALR2 inhibitory chalcones. On the other hand, the data for some other targets are less convincing and deserve further investigations.

In conclusion, we have attempted to summarize the current knowledge of potential direct molecular targets of chalcone compounds in this review. The wide variety of their potential targets explains at least partly the diverse bioactivities of chalcones, which presents both opportunities and challenges in developing chalcone-based therapeutic agents. A better understanding of the interaction modes and biological relevance of such interactions would greatly facilitate further development of chalcone-based therapeutic agents.

\section{Acknowledgement}

This work was supported by grants from NIH (CA163864, CX).

\section{References}

1. Batovska DI, Todorova IT (2010) Trends in utilization of the pharmacological potential of chalcones. Curr Clin Pharmacol 5: 1-29.

2. Sahu NK, Balbhadra SS, Choudhary J, Kohli DV (2012) Exploring pharmacological significance of chalcone scaffold: a review. Curr Med Chem 19: $209-225$

3. Singh P, Anand A, Kumar V (2014) Recent developments in biological activities of chalcones: a mini review. Eur J Med Chem 85: 758-777.

4. Karthikeyan C, Moorthy NS, Ramasamy S, Vanam U, Manivannan E, et al. (2015) Advances in chalcones with anticancer activities. Recent Pat Anticancer Drug Discov 10: 97-115.

5. Mahapatra DK, Bharti SK, Asati V (2015) Anti-cancer chalcones: Structural and molecular target perspectives European journal of medicinal chemistry 98: 69-114.

6. Orlikova B, Tasdemir D, Golais F, Dicato M, Diederich M (2011) Dietary chalcones with chemopreventive and chemotherapeutic potential. Genes Nutr 6: $125-147$.

7. Go ML, Wu X, Liu XL (2005) Chalcones: an update on cytotoxic and chemoprotective properties. Curr Med Chem 12: 481-499.

8. Boumendjel A, Ronot X, Boutonnat J (2009) Chalcones derivatives acting as cell cycle blockers: potential anti cancer drugs? Curr Drug Targets 10: 363-371.

9. Yadav VR, Prasad S, Sung B, Aggarwal BB (2011) The role of chalcones in suppression of NF-kB-mediated inflammation and cancer. Int Immunopharmacol 11: 295-309.
10. Bukhari SN, Jantan I, Jasamai M (2013) Anti-inflammatory trends of, 3-diphenyl2-propen-1-one derivatives. Mini Rev Med Chem 13: 87-94.

11. Kontogiorgis C, Mantzanidou M, Hadjipavlou-Litina D (2008) Chalcones and their potential role in inflammation. Mini Rev Med Chem 8: 1224-1242.

12. Mahapatra DK, Asati V, Bharti SK (2015) Chalcones and their therapeutic targets for the management of diabetes: structural and pharmacological perspectives. Eur J Med Chem 92: 839-865

13. Dumontet C, Jordan MA (2010) Microtubule-binding agents: a dynamic field of cancer therapeutics. Nat Rev Drug Discov 9: 790-803.

14. Jordan MA, Wilson L (2004) Microtubules as a target for anticancer drugs. Nat Rev Cancer 4: 253-265.

15. Peyrot V, Leynadier D, Sarrazin M, Briand C, Rodriquez A, et al. (1989) Interaction of tubulin and cellular microtubules with the new antitumor drug MDL 27048. A powerful and reversible microtubule inhibitor. J Biol Chem 264 21296-21301.

16. Peyrot V, Leynadier D, Sarrazin M, Briand C, Menendez M, et al. (1992) Mechanism of binding of the new antimitotic drug MDL 27048 to the colchicine site of tubulin: equilibrium studies. Biochemistry 31: 11125-11132.

17. Silence K, D'Hoore A, Engelborghs Y, Peyrot V, Briand C (1992) Fluorescence stopped-flow study of the interaction of tubulin with the antimitotic drug MDL 27048. Biochemistry 31: 11133-11137.

18. Ducki S, Mackenzie G, Lawrence NJ, Snyder JP (2005) Quantitative structureactivity relationship (5D-QSAR) study of combretastatin-like analogues as inhibitors of tubulin assembly. J Med Chem 48: 457-465.

19. Ducki S, Rennison D, Woo M, Kendall A, Chabert JF, et al. (2009) Combretastatin-like chalcones as inhibitors of microtubule polymerization. Part 1: synthesis and biological evaluation of antivascular activity. Bioorg Med Chem 17: 7698-7710.

20. Kim do Y, Kim KH, Kim ND, Lee KY, Han CK, et al. (2006) Design and biological evaluation of novel tubulin inhibitors as antimitotic agents using a pharmacophore binding model with tubulin. J Med Chem 49: 5664-5670.

21. Alias $\mathrm{Y}$, Awang K, Hadi AH, Thoison O, Sevenet T, et al. (1995) An antimitotic and cytotoxic chalcone from Fissistigma lanuginosum. J Nat Prod 58: 1160-1166.

22. Lawrence NJ, McGown AT, Ducki S, Hadfield JA (2000) The interaction of chalcones with tubulin. Anticancer Drug Des 15: 135-141.

23. Boumendjel A, McLeer-Florin A, Champelovier P, Allegro D, Muhammad $D$, et al. (2009) A novel chalcone derivative which acts as a microtubule depolymerising agent and an inhibitor of P-gp and BCRP in in-vitro and in-vivo glioblastoma models. BMC cancer 9: 242.

24. Martel-Frachet V, Keramidas M, Nurisso A, DeBonis S, Rome C, et al. (2015) IPP5, a chalcone acting as a microtubule inhibitor with in vivo antitumor activity against bladder carcinoma. Oncotarget 6: 14669-14686.

25. Dyrager C, Wickstrom M, Friden-Saxin M, Friberg A, Dahlen K, et al. (2011) Inhibitors and promoters of tubulin polymerization: synthesis and biological evaluation of chalcones and related dienones as potential anticancer agents. Bioorganic \& medicinal chemistry 19: 2659-2665.

26. Zhang H, Liu JJ, Sun J, Yang XH, Zhao TT, et al. (2012) Design, synthesis and biological evaluation of novel chalcone derivatives as antitubulin agents. Bioorg Med Chem 20: 3212-3218.

27. Salum LB, Altei WF, Chiaradia LD, Cordeiro MN, Canevarolo RR, et al. (2013) Cytotoxic 3,4,5-trimethoxychalcones as mitotic arresters and cell migration inhibitors. Eur J Med Chem 63: 501-510.

28. Shin SY, Kim JH, Yoon H, Choi YK, Koh D, et al. (2013) Novel antimitotic activity of 2-hydroxy-4-methoxy-2',3'-benzochalcone (HymnPro) through the inhibition of tubulin polymerization. J Agric Food Chem 61: 12588-12597.

29. Lee JM, Lee MS, Koh D, Lee YH, Lim Y, et al. (2014) A new synthetic 2'-hydroxy-2,4,6-trimethoxy-5',6'-naphthochalcone induces $\mathrm{G} 2 / \mathrm{M}$ cell cycle arrest and apoptosis by disrupting the microtubular network of human colon cancer cells. Cancer Lett 354: 348-354.

30. Zhu C, Zuo Y, Wang R, Liang B, Yue X, et al. (2014) Discovery of potent cytotoxic ortho-aryl chalcones as new scaffold targeting tubulin and mitosis with affinity-based fluorescence. Journal of medicinal chemistry $57: 6364-6382$.

31. Konieczny MT, Buakowska A, Pirska D, Konieczny W, Skladanowski A, et al (2015) Structural factors affecting affinity of cytotoxic oxathiole-fused chalcones toward tubulin. European journal of medicinal chemistry 89: 733-742. 
Citation: Zhou B, Xing C (2015) Diverse Molecular Targets for Chalcones with Varied Bioactivities. Med chem 5: 388-404. doi: 10.4172/21610444.1000291

32. Wang G, Peng F, Cao D, Yang Z, Han X, et al. (2013) Design, synthesis and biological evaluation of millepachine derivatives as a new class of tubulin polymerization inhibitors. Bioorganic \& medicinal chemistry 2: 6844-6854.

33. Wang G, Li C, He L, Lei K, Wang F, et al. (2014) Design, synthesis and biological evaluation of a series of pyrano chalcone derivatives containing indole moiety as novel anti-tubulin agents. Bioorganic \& medicinal chemistry 22: 2060-2079.

34. Yang Z, Wu W, Wang J, Liu L, Li L, et al. (2014) Synthesis and biological evaluation of novel millepachine derivatives as a new class of tubulin polymerization inhibitors. J Med Chem 57: 7977-7989.

35. Ruan BF, Lu X, Tang JF, Wei $Y$, Wang XL, et al. (2011) Synthesis, biological evaluation, and molecular docking studies of resveratrol derivatives possessing chalcone moiety as potential antitubulin agents. Bioorganic \& medicinal chemistry 19: 2688-2695.

36. Kamal A, Mallareddy A, Suresh P, Shaik TB, Lakshma Nayak V, et al. (2012) Synthesis of chalcone-amidobenzothiazole conjugates as antimitotic and apoptotic inducing agents. Bioorganic \& medicinal chemistry 20: 3480-3492.

37. Kamal A, Kumar GB, Vishnuvardhan MV, Shaik AB, Reddy VS, et al. (2015) Synthesis of phenstatin/isocombretastatin-chalcone conjugates as potent tubulin polymerization inhibitors and mitochondrial apoptotic inducers. Organic \& biomolecular chemistry 13: 3963-3981.

38. Fabbro D, Cowan-Jacob SW, Moebitz H (2015) Ten things you should know about protein kinases: IUPHAR Review 14. Br J Pharmacol 172: 2675-2700.

39. Cohen P (2002) Protein kinases--the major drug targets of the twenty-first century? Nat Rev Drug Discov 1: 309-315.

40. Rask-Andersen M, Zhang J, Fabbro D, Schioth HB (2014) Advances in kinase targeting: current clinical use and clinical trials. Trends Pharmacol Sci 35: 604-620.

41. Fabbro D (2015) 25 years of small molecular weight kinase inhibitors: potentials and limitations. Mol Pharmacol 87: 766-775.

42. Baldwin AS (2012) Regulation of cell death and autophagy by IKK and NF-KB: critical mechanisms in immune function and cancer. Immunol Rev 246: 327345 .

43. Gamble C, McIntosh K, Scott R, Ho KH, Plevin R, et al. (2012) Inhibitory kappa B Kinases as targets for pharmacological regulation. Br J Pharmacol 165: 802-819.

44. Pandey MK, Sandur SK, Sung B, Sethi G, Kunnumakkara AB, et al. (2007) Butein, a tetrahydroxychalcone, inhibits nuclear factor (NF)-kappaB and NFkappaB-regulated gene expression through direct inhibition of IkappaBalpha kinase beta on cysteine 179 residue. The Journal of biological chemistry 282 : 17340-17350.

45. Funakoshi-Tago M, Tanabe S, Tago K, Itoh H, Mashino T, et al. (2009) Licochalcone A potently inhibits tumor necrosis factor alpha-induced nuclear factor-kappaB activation through the direct inhibition of lkappaB kinase complex activation. Molecular pharmacology 76: 745-753.

46. Harikumar KB, Kunnumakkara AB, Ahn KS, Anand P, Krishnan S, et al. (2009) Modification of the cysteine residues in IkappaBalpha kinase and NF-kappaB (p65) by xanthohumol leads to suppression of NF-kappaB-regulated gene products and potentiation of apoptosis in leukemia cells. Blood 113: 2003-2013.

47. Bayon Y, Ortiz MA, Lopez-Hernandez FJ, Gao F, Karin M, et al. (2003) Inhibition of IkappaB kinase by a new class of retinoid-related anticancer agents that induce apoptosis. Molecular and cellular biology 23: 1061-1074.

48. Lorenzo P, Alvarez R, Ortiz MA, Alvarez S, Piedrafita FJ, et al. (2008) Inhibition of IkappaB kinase-beta and anticancer activities of novel chalcone adamantyl arotinoids. J Med Chem 51: 5431-5440.

49. Lorenzo P, Ortiz MA, Alvarez R, Piedrafita FJ, de Lera AR (2013) Adamantyl arotinoids that inhibit lî ${ }^{\circ} \mathrm{B}$ kinase $\alpha$ and $\mathrm{kB}$ kinase $\beta$. Chem Med Chem 8: $1184-$ 1198.

50. Garcia-Rodriguez J, Perez-Rodriguez S, Ortiz MA, Pereira R, de Lera AR, et al. (2014) Inhibition of IkappaB kinase-beta and IkappaB kinase-alpha by heterocyclic adamantyl arotinoids. Bioorganic \& medicinal chemistry 22: 12851302.

51. Kelly KR, Ecsedy J, Mahalingam D, Nawrocki ST, Padmanabhan S, et al. (2011) Targeting aurora kinases in cancer treatment. Curr Drug Targets 12: 2067-2078.

52. Limper C, Wang Y, Ruhl S, Wang Z, Lou Y, et al. (2013) Compounds isolated from Psoralea corylifolia seeds inhibit protein kinase activity and induce apoptotic cell death in mammalian cells. J Pharm Pharmacol 65: 1393-1408.

53. Shin SY, Yoon H, Ahn S, Kim DW, Kim SH, et al. (2013) Chromenylchalcones showing cytotoxicity on human colon cancer cell lines and in silico docking with aurora kinases. Bioorg Med Chem 21: 4250-4258.

54. Shin SY, Jung H, Ahn S, Hwang D, Yoon H, et al. (2014) Polyphenols bearing cinnamaldehyde scaffold showing cell growth inhibitory effects on the cisplatinresistant A2780/Cis ovarian cancer cells. Bioorganic \& medicinal chemistry 22 : 1809-1820.

55. Schlessinger J (2014) Receptor tyrosine kinases: legacy of the first two decades. Cold Spring Harb Perspect Biol 6.

56. Hojjat-Farsangi M (2014) Small-molecule inhibitors of the receptor tyrosine kinases: promising tools for targeted cancer therapies. International journal of molecular sciences 15: 13768-13801.

57. Yang EB, Zhang K, Cheng LY, Mack $P$ (1998) Butein, a specific protein tyrosine kinase inhibitor. Biochemical and biophysical research communications 245 435-438.

58. Yang EB, Guo YJ, Zhang K, Chen YZ, Mack P (2001) Inhibition of epidermal growth factor receptor tyrosine kinase by chalcone derivatives. Biochim Biophys Acta 1550: 144-152.

59. Jung SK, Lee MH, Lim do Y, Kim JE, Singh $P$, et al. (2014) Isoliquiritigenin induces apoptosis and inhibits xenograft tumor growth of human lung cancer cells by targeting both wild type and L858R/T790M mutant EGFR. J Biol Chem 289: 35839-35848.

60. Wang Z, Wang N, Han S, Wang D, Mo S, et al. (2013) Dietary compound isoliquiritigenin inhibits breast cancer neoangiogenesis via VEGF/VEGFR-2 signaling pathway. PLoS One 8: e68566.

61. Lee JS, Kang Y, Kim JT, Thapa D, Lee ES, et al. (2012) The anti-angiogenic and anti-tumor activity of synthetic phenylpropenone derivatives is mediated through the inhibition of receptor tyrosine kinases. Eur J Pharmacol 677: 22-30.

62. Jing H, Zhou X, Dong X, Cao J, Zhu H, et al. (2010) Abrogation of Akt signaling by Isobavachalcone contributes to its anti-proliferative effects towards human cancer cells. Cancer Lett 294: 167-177.

63. Song NR, Kim JE, Park JS, et al. (2015) Licochalcone A, a polyphenol present in licorice, suppresses UV-induced COX-2 expression by targeting PI3K, MEK and B-Raf. Int J Mol Sci 16: 4453-4470.

64. Wang JP, Tsao LT, Raung SL, Lin CN (1997) Investigation of the inhibitory effect of broussochalcone A on respiratory burst in neutrophils. Eur J Pharmaco 320: $201-208$

65. Claria J, Romano M (2005) Pharmacological intervention of cyclooxygenase-2 and 5-lipoxygenase pathways. Impact on inflammation and cancer. Curr Pharm Des 11: 3431-3447.

66. Goossens L, Pommery N, Henichart JP (2007) COX-2/5-LOX dual acting antiinflammatory drugs in cancer chemotherapy. Curr Top Med Chem 7: 283-296.

67. Sogawa S, Nihro Y, Ueda H, Izumi A, Miki T, et al. (1993)3,4-Dihydroxychalcones as potent 5-lipoxygenase and cyclooxygenase inhibitors. J Med Chem 36: 3904-3909.

68. Lin CN, Lu CM, Lin HC, Fang SC, Shieh BJ, et al. (1996) Novel antiplatelet constituents from formosan moraceous plants. J Nat Prod 59: 834-838.

69. Lin CN, Lee TH, Hsu MF, Wang JP, Ko FN, et al. (1997) 2',5'-Dihydroxychalcone as a potent chemical mediator and cyclooxygenase inhibitor. J Pharm Pharmacol 49: 530-536.

70. Herencia F, Ferrandiz ML, Ubeda A, Dominguez JN, Charris JE, et al. (1998) Synthesis and anti-inflammatory activity of chalcone derivatives. Bioorg Med Chem Lett 8: 1169-1174.

71. Gerhauser C, Alt A, Heiss E, Gamal-Eldeen A, Klimo K, et al. (2002) Cancer chemopreventive activity of Xanthohumol, a natural product derived from hop. Molecular cancer therapeutics 1: 959-969.

72. Araico A, Terencio MC, Alcaraz MJ, Dominguez JN, Leon C, et al. (2006) Phenylsulphonyl urenyl chalcone derivatives as dual inhibitors of cyclooxygenase-2 and 5-lipoxygenase. Life Sci 78: 2911-2918.

73. Zarghi A, Arfaee S, Rao PN, Knaus EE (2006) Design, synthesis, and biological evaluation of 3-diarylprop-2-en-1-ones : a novel class of cyclooxygenase-2 inhibitors. Bioorg Med Chem 14: 2600-2605.

74. Tran TD, Park H, Kim HP, Ecker GF, Thai KM (2009) Inhibitory activity of prostaglandin E2 production by the synthetic 2'-hydroxychalcone analogues: Synthesis and SAR study. Bioorg Med Chem Lett 19: 1650-1653.

75. El-Sabbagh OI, Mostafa S, Abdel-Aziz HA, Ibrahim HS, Elaasser MM (2013) 
Synthesis and biological evaluation of some $\mathrm{N}$-arylpyrazoles and pyrazolo[3,4-d] pyridazines as anti-inflammatory agents. Arch Pharm (Weinheim) 346: 688-698.

76. Jantan I, Bukhari SN, Adekoya OA, Sylte I (2014) Studies of synthetic chalcone derivatives as potential inhibitors of secretory phospholipase A2, cyclooxygenases, lipoxygenase and pro-inflammatory cytokines. Drug design, development and therapy 8: 1405-1418.

77. Wu CM, Lin KW, Teng CH, Huang AM, Chen YC, et al. (2014) Chalcone derivatives inhibit human platelet aggregation and inhibit growth in human bladder cancer cells. Biological \& pharmaceutical bulletin 37: 1191-1198.

78. Bukhari SN, Zhang X, Jantan I, Zhu HL, Amjad MW, et al. (2015) Synthesis, Molecular Modeling, and Biological Evaluation of Novel, 3-Diphenyl-2-propen1-one Based Pyrazolines as Anti-inflammatory Agents. Chem Biol Drug Des 85: 729-742.

79. Ozdemir A, Altintop MD, Turan-Zitouni G, Ciftci GA, Ertorun I, et al. (2015) Synthesis and evaluation of new indole-based chalcones as potential antiinflammatory agents. Eur J Med Chem 89: 304-309.

80. Casanola-Martin GM, Le-Thi-Thu H, Marrero-Ponce Y, Castillo-Garit JA, Torrens F, et al. (2014) Tyrosinase enzyme: 1. An overview on a pharmacological target. Curr Top Med Chem 14: 1494-1501.

81. Nerya O, Vaya J, Musa R, Izrael S, Ben-Arie R, et al. (2003) Glabrene and isoliquiritigenin as tyrosinase inhibitors from licorice roots. J Agric Food Chem 51: 1201-1207.

82. Nerya O, Musa R, Khatib S, Tamir S, Vaya J (2004) Chalcones as potent tyrosinase inhibitors: the effect of hydroxyl positions and numbers. Phytochemistry 65: 1389-1395.

83. Khatib S, Nerya O, Musa R, Shmuel M, Tamir S, et al. (2005) Chalcones as potent tyrosinase inhibitors: the importance of a 2,4-substituted resorcinol moiety. Bioorg Med Chem 13: 433-441.

84. Jun N, Hong G, Jun K (2007) Synthesis and evaluation of $2^{\prime}, 4^{\prime}, 6$ '-trihydroxychalcones as a new class of tyrosinase inhibitors. Bioorg Med Chem 15: 2396-2402.

85. Zhang X, Hu X, Hou A, Wang H (2009) Inhibitory effect of 2,4,2',4'-tetrahydroxy3-(3-methyl-2-butenyl)-chalcone on tyrosinase activity and melanin biosynthesis. Biol Pharm Bull 32: 86-90.

86. Seo WD, Ryu YB, Curtis-Long MJ, Lee CW, Ryu HW, et al. (2010) Evaluation of anti-pigmentary effect of synthetic sulfonylamino chalcone. Eur J Med Chem 45: 2010-2017.

87. Green SM, Mostaghel EA, Nelson PS (2012) Androgen action and metabolism in prostate cancer. Mol Cell Endocrinol 360: 3-13.

88. Samavat H, Kurzer MS (2015) Estrogen metabolism and breast cancer. Cancer Lett 356: 231-243.

89. Le Bail JC, Pouget C, Fagnere C, Basly JP, Chulia AJ, et al. (2001) Chalcones are potent inhibitors of aromatase and 17beta-hydroxysteroid dehydrogenase activities. Life Sci 68: 751-761.

90. Lee D, Bhat KP, Fong HH, Farnsworth NR, Pezzuto JM, et al. (2001) Aromatase inhibitors from Broussonetia papyrifera. J Nat Prod 64: 1286-1293.

91. Wang Y, Chan FL, Chen S, Leung LK (2005) The plant polyphenol butein inhibits testosterone-induced proliferation in breast cancer cells expressing aromatase. Life Sci 77: 39-51.

92. Monteiro R, Faria A, Azevedo I, Calhau C (2007) Modulation of breast cance cell survival by aromatase inhibiting hop (Humulus lupulus L.) flavonoids. J Steroid Biochem Mol Biol 105: 124-130.

93. Shimiz K, Kondo R, Sakai K, Buabarn S, Dilokkunanant U (2000) A geranylated chalcone with 5alpha-reductase inhibitory properties from Artocarpus incisus. Phytochemistry 54: 737-739.

94. Hussein SA, Hashim AN, Barakat HH, Jose J, Lindequist U, et al. (2006) Phenolics from extracts of Brahea armata with inhibitory effect against 5alphareductase type-II. Pharmazie 61: 1034-1037.

95. Chatzopoulou M, Pegklidou K, Papastavrou N, Demopoulos VJ (2013) Development of aldose reductase inhibitors for the treatment of inflammatory disorders. Expert Opin Drug Discov 8: 1365-1380.

96. Maccari R, Ottana R (2015) Targeting aldose reductase for the treatment of diabetes complications and inflammatory diseases: new insights and future directions. J Med Chem 58: 2047-2067.

97. Aida K, Tawata M, Shindo H, Onaya T, Sasaki H, et al. (1989) The existence of aldose reductase inhibitors in some kampo medicines (Oriental herb prescriptions). Planta Med 55: 22-26.

98. Aida K, Tawata M, Shindo H, Onaya T, Sasaki H, et al. (1990) Isoliquiritigenin a new aldose reductase inhibitor from glycyrrhizae radix. Planta Med 56: 254 258.

99. Jung HA, Yoon NY, Kang SS, Kim YS, Choi JS (2008) Inhibitory activities of prenylated flavonoids from Sophora flavescens against aldose reductase and generation of advanced glycation endproducts. J Pharm Pharmacol 60: 12271236

100. Lim SS, Jung SH, Ji J, Shin KH, Keum SR (2001) Synthesis of flavonoids and their effects on aldose reductase and sorbitol accumulation in streptozotocininduced diabetic rat tissues. J Pharm Pharmacol 53: 653-668.

101. Rastelli G, Antolini L, Benvenuti S, Costantino L (2000) Structural bases for the inhibition of aldose reductase by phenolic compounds. Bioorg Med Chem 8: $1151-1158$.

102. Severi F, Benvenuti S, Costantino L, Vampa G, Melegari M, et al. (1998) Synthesis and activity of a new series of chalcones as aldose reductase inhibitors. European journal of medicinal chemistry 33: 859-866.

103.Lim SS, Jung SH, Ji J, Shin KH, Keum SR (2000) Inhibitory effects of 2 '-hydroxychalcones on rat lens aldose reductase and rat platelet aggregation. Chem Pharm Bull (Tokyo) 48: 1786-1789.

104. Iwata S, Nagata N, Omae A, Yamaguchi S, Okada Y, et al. (1999) Inhibitory effect of chalcone derivatives on recombinant human aldose reductase. Biol Pharm Bull 22: 323-325.

105. Liu Y, Li Y, Yu S, Zhao G (2012) Recent advances in the development of thioredoxin reductase inhibitors as anticancer agents. Curr Drug Targets 13 $1432-1444$

106. Mahmood DF, Abderrazak A, El Hadri K, Simmet T, Rouis M (2013) The thioredoxin system as a therapeutic target in human health and disease. Antioxid Redox Signal 19: 1266-1303.

107. Gan FF, Kaminska KK, Yang H, Liew CY, Leow PC, et al. (2013) Identification of Michael acceptor-centric pharmacophores with substituents that yield strong thioredoxin reductase inhibitory character correlated to antiproliferative activity. Antioxidants \& redox signaling 19: 1149-1165.

108.Zhang B, Duan D, Ge C, Yao J, Liu Y, et al. (2015) Synthesis of xanthohumol analogues and discovery of potent thioredoxin reductase inhibitor as potential anticancer agent. J Med Chem 58: 1795-1805.

109. Naoi M, Maruyama W, Inaba-Hasegawa K (2012) Type A and B monoamine oxidase in age-related neurodegenerative disorders: their distinct roles in neuronal death and survival. Current topics in medicinal chemistry 12: 2177 2188.

110. Tanaka S, Kuwai Y, Tabata M (1987) Isolation of monoamine oxidase inhibitors from Glycyrrhiza uralensis roots and the structure-activity relationship. Planta Med 53: 5-8.

111. Chimenti F, Fioravanti R, Bolasco A, Chimenti P, Secci D, et al. (2009) Chalcones: a valid scaffold for monoamine oxidases inhibitors. J Med Chem 52: $2818-2824$

112. Robinson SJ, Petzer JP, Petzer A, Bergh JJ, Lourens AC (2013) Selected furanochalcones as inhibitors of monoamine oxidase. Bioorg Med Chem Let 23: 4985-4989.

113. Fonović M, Turk B (2014) Cysteine cathepsins and their potential in clinical therapy and biomarker discovery. Proteomics Clin Appl 8: 416-426.

114. Kim SH, Lee E, Baek KH, Kwon HB, Woo H, et al. (2013) Chalcones, inhibitors for topoisomerase $\mathrm{I}$ and cathepsin $\mathrm{B}$ and $\mathrm{L}$, as potential anti-cancer agents. Bioorg Med Chem Lett 23: 3320-3324.

115. Ramalho SD, Bernades A, Demetrius G, Noda-Perez C, Vieira PC, et al (2013) Synthetic chalcone derivatives as inhibitors of cathepsins $K$ and $B$, and their cytotoxic evaluation. Chem Biodivers 10: 1999-2006.

116. Raghav, N., and Garg, S. (2014) SAR studies of o-hydroxychalcones and their cyclized analogs and study them as novel inhibitors of cathepsin $B$ and cathepsin $\mathrm{H}$. European journal of pharmaceutical sciences 60: 55-63.

117. Yan R, Vassar $R$ (2014) Targeting the $\beta$ secretase BACE1 for Alzheimer's disease therapy. Lancet Neurol 13: 319-329.

118. Ma L, Yang Z, Li C, Zhu Z, Shen X, et al. (2011) Design, synthesis and SAR study of hydroxychalcone inhibitors of human $\beta$-secretase (BACE1). J Enzyme Inhib Med Chem 26: 643-648. 
Citation: Zhou B, Xing C (2015) Diverse Molecular Targets for Chalcones with Varied Bioactivities. Med chem 5: 388-404. doi: 10.4172/21610444.1000291

119. Kang JE, Cho JK, Curtis-Long MJ, Ryu HW, Kim JH, et al. (2012) Inhibitory evaluation of sulfonamide chalcones on $\beta$-secretase and acylcholinesterase. Molecules 18: 140-153.

120. Falkenberg KJ, Johnstone RW (2014) Histone deacetylases and their inhibitors in cancer, neurological diseases and immune disorders. Nat Rev Drug Discov 13: 673-691.

121. Abend A, Kehat I (2015) Histone deacetylases as therapeutic targets--from cancer to cardiac disease. Pharmacol Ther 147: 55-62.

122. Orlikova B, Schnekenburger M, Zloh M, Golais F, Diederich M, et al. (2012) Natural chalcones as dual inhibitors of HDACs and NF-kB. Oncol Rep 28: 797-805.

123.Zhou J, Li M, Chen N, Wang S, Luo HB, et al. (2015) Computational design of a time-dependent histone deacetylase 2 selective inhibitor. ACS Chem Biol 10: $687-692$.

124. Kahyo T, Ichikawa S, Hatanaka T, Yamada MK, Setou M (2008) A novel chalcone polyphenol inhibits the deacetylase activity of SIRT1 and cell growth in HEK293T cells. J Pharmacol Sci 108: 364-371.

125.Lane RM, Potkin SG, Enz A (2006) Targeting acetylcholinesterase and butyrylcholinesterase in dementia. The international journal of neuropsychopharmacology/official scientific journal of the Collegium Internationale Neuropsychopharmacologicum 9, 101-124.

126.Larner AJ (2010) Cholinesterase inhibitors: beyond Alzheimer's disease. Expert Rev Neurother 10: 1699-1705

127.Ansari FL, Umbreen S, Hussain L, Makhmoor T, Nawaz SA., et al. (2005) Syntheses and biological activities of chalcone and ,5-benzothiazepine derivatives: promising new free-radical scavengers, and esterase, urease, and alpha-glucosidase inhibitors. Chemistry \& biodiversity 2: 487-496.

128. Liu HR, Liu XJ, Fan HQ, Tang JJ, Gao XH, et al. (2014) Design, synthesis and pharmacological evaluation of chalcone derivatives as acetylcholinesterase inhibitors. Bioorganic \& medicinal chemistry 22: 6124-6133.

129. Liu HR, Zhou C, Fan HQ, Tang JJ, Liu LB, et al. (2015) Novel Potent and Selective Acetylcholinesterase Inhibitors as Potential Drugs for the Treatment of Alzheimer's Disease: Synthesis, Pharmacological Evaluation, and Molecular Modeling of Amino-Alkyl-Substituted Fluoro-Chalcones Derivatives, Chemical biology \& drug design.

130.Zhang S, Zhang ZY (2007) PTP1B as a drug target: recent developments in PTP1B inhibitor discovery. Drug Discov Today 12: 373-381.

131.Lavecchia A, Coluccia A, Di Giovanni C, Novellino E (2008) Cdc25B phosphatase inhibitors in cancer therapy: latest developments, trends and medicinal chemistry perspective. Anticancer Agents Med Chem 8: 843-856.

132. Chen RM, Hu LH, An TY, Li J, Shen Q (2002) Natural PTP1B inhibitors from Broussonetia papyrifera. Bioorg Med Chem Lett 12: 3387-3390.

133. Yoon G, Lee W, Kim SN, Cheon SH (2009) Inhibitory effect of chalcones and their derivatives from Glycyrrhiza inflata on protein tyrosine phosphatase 1B. Bioorg Med Chem Lett 19: 5155-5157.

134.Li JL, Gao LX, Meng FW, Tang CL, Zhang RJ, et al. (2015) PTP1B inhibitors from stems of Angelica keiskei (Ashitaba). Bioorg Med Chem Lett 25: 20282032

135.Zhang J, Ji FJ, Gu Y, Zhang XY, Qiao SX (2014) Chalcones derivatives as potent Cell division cycle 25B phosphatase inhibitors. Pharmacol Rep 66: 515-519.

136. Sun LP, Gao LX, Ma WP, Nan FJ, Li J, et al. (2012) Synthesis and biological evaluation of 2,4,6-trihydroxychalcone derivatives as novel protein tyrosine phosphatase 1B inhibitors. Chem Biol Drug Des 80: 584-590.

137.Xie C, Sun Y, Pan CY, Tang LM, Guan LP (2014) 2,4-Dihydroxychalcone derivatives as novel potent cell division cycle 25B phosphatase inhibitors and protein tyrosine phosphatase 1B inhibitors. Pharmazie 69: 257-262.

138. Quach ND, Arnold RD, Cummings BS (2014) Secretory phospholipase A2 enzymes as pharmacological targets for treatment of disease. Biochem Pharmacol 90: 338-348.

139. Ballesteros JF, Sanz MJ, Ubeda A, Miranda MA, Iborra S, et al. (1995) Synthesis and pharmacological evaluation of 2'-hydroxychalcones and flavones as inhibitors of inflammatory mediators generation. J Med Chem 38: 2794-2797.

140. Van de Laar FA, Lucassen PL, Akkermans RP, Van de Lisdonk EH, Rutten
GE, et al. (2005) Alpha-glucosidase inhibitors for type 2 diabetes mellitus. Cochrane Database Syst Rev : CD003639.

141. Kim JH, Ryu YB, Kang NS, Lee BW, Heo JS, et al. (2006) Glycosidase inhibitory flavonoids from Sophora flavescens. Biol Pharm Bull 29: 302-305.

142. Liu M, Yin H, Liu G, Dong J, Qian Z, et al. (2014) Xanthohumol, a prenylated chalcone from beer hops, acts as an a-glucosidase inhibitor in vitro. J Agric Food Chem 62: 5548-5554.

143. Chinthala Y, Thakur S, Tirunagari S, Chinde S, Domatti AK, et al. (2015) Synthesis, docking and ADMET studies of novel chalcone triazoles for anticancer and anti-diabetic activity. Eur J Med Chem 93: 564-573.

144. Seo WD, Kim JH, Kang JE, Ryu HW, Curtis-Long MJ, et al. (2005) Sulfonamide chalcone as a new class of alpha-glucosidase inhibitors. Bioorg Med Chem Lett 15: 5514-5516.

145. Chiaradia LD, Mascarello A, Purificacao M, Vernal J, Cordeiro MN, et al. (2008) Synthetic chalcones as efficient inhibitors of Mycobacterium tuberculosis protein tyrosine phosphatase PtpA. Bioorganic \& medicinal chemistry letters 18: $6227-6230$

146. Chiaradia LD, Martins PG, Cordeiro MN, Guido RV, Ecco G, et al. (2012) Synthesis, biological evaluation, and molecular modeling of chalcone derivatives as potent inhibitors of Mycobacterium tuberculosis protein tyrosine phosphatases (PtpA and PtpB). Journal of medicinal chemistry 55: 390-402.

147. Mascarello A, Chiaradia LD, Vernal J, Villarino A, Guido RV, et al. (2010) Inhibition of Mycobacterium tuberculosis tyrosine phosphatase PtpA by synthetic chalcones: kinetics, molecular modeling, toxicity and effect on growth. Bioorganic \& medicinal chemistry 18: 3783-3789.

148. Martins PG, Menegatti AC, Chiaradia-Delatorre LD, de Oliveira KN, Guido RV, et al. (2013) Synthetic chalcones and sulfonamides as new classes of Yersinia enterocolitica $\mathrm{YopH}$ tyrosine phosphatase inhibitors. European journal of medicinal chemistry $64: 35-41$.

149. Deng J, Kelley JA, Barchi JJ, Sanchez T, Dayam R, et al. (2006) Mining the $\mathrm{NCl}$ antiviral compounds for HIV-1 integrase inhibitors. Bioorg Med Chem 14 3785-3792.

150. Sharma H, Patil S, Sanchez TW, Neamati N, Schinazi RF, et al. (2011) Synthesis, biological evaluation and 3D-QSAR studies of 3-keto salicylic acid chalcones and related amides as novel HIV-1 integrase inhibitors. Bioorg Med Chem 19: 2030-2045.

151. Geyer JA, Keenan SM, Woodard CL, Thompson PA, Gerena L, et al. (2009) Selective inhibition of Pfmrk, a Plasmodium falciparum CDK, by antimalarial ,3-diaryl-2-propenones. Bioorganic \& medicinal chemistry letters 19: 19821985.

152. Battenberg OA, Yang Y, Verhelst SH, Sieber SA (2013) Target profiling of 4-hydroxyderricin in $\mathrm{S}$. aureus reveals seryl-tRNA synthetase binding and inhibition by covalent modification. Mol Biosyst 9: 343-351.

153. Wallock-Richards DJ, Marles-Wright J, Clarke DJ, Maitra A, Dodds M, et al. (2015) Molecular basis of Streptococcus mutans sortase A inhibition by the flavonoid natural product trans-chalcone. Chemical communications 5: 1048310485.

154. Abdullah MI, Mahmood A, Madni M, Masood S, Kashif M (2014) Synthesis, characterization, theoretical, anti-bacterial and molecular docking studies of quinoline based chalcones as a DNA gyrase inhibitor. Bioorganic chemistry 54: 31-37.

155. Duong V, Rochette-Egly C (2011) The molecular physiology of nuclear retinoic acid receptors. From health to disease. Biochim Biophys Acta 1812: 10231031

156. Kagechika H, Kawachi E, Hashimoto Y, Shudo K (1989) Retinobenzoic acids 2. Structure-activity relationships of chalcone-4-carboxylic acids and flavone4'-carboxylic acids. J Med Chem 32: 834-840.

157. Von Schroeder HP, Hashimoto Y, Heersche JN (1994) The effects of natural and synthetic retinoids on the differentiation of RCJ C 5.18 chondrogenic cells. Teratology 50: 54-62.

158. Klaholz BP, Mitschler A, Moras D (2000) Structural basis for isotype selectivity of the human retinoic acid nuclear receptor. $\mathrm{J} \mathrm{Mol} \mathrm{Biol} \mathrm{302:} \mathrm{155-170.}$

159.Paterni I, Bertini S, Granchi C, Macchia M, Minutolo F (2013) Estrogen receptor ligands: a patent review update. Expert opinion on therapeutic patents 23: 1247-1271.

160.Tamir S, Eizenberg M, Somjen D, Izrael S, Vaya J (2001) Estrogen-like 
Citation: Zhou B, Xing C (2015) Diverse Molecular Targets for Chalcones with Varied Bioactivities. Med chem 5: 388-404. doi: 10.4172/21610444.1000291

activity of glabrene and other constituents isolated from licorice root. J Steroid Biochem Mol Biol 78: 291-298.

161. Hajirahimkhan A, Simmler C, Yuan Y, Anderson JR, Chen SN, et al. (2013) Evaluation of estrogenic activity of licorice species in comparison with hops used in botanicals for menopausal symptoms. PLoS One 8: e67947.

162. Hegazy ME, El-Hamd H Mohamed A, El-Halawany AM, Djemgou PC, Shahat AA, et al. (2011) Estrogenic activity of chemical constituents from Tephrosia candida. J Nat Prod 74: 937-942.

163. Cho S, Kim S, Jin Z, Yang H, Han D, et al. (2011) Isoliquiritigenin, a chalcone compound, is a positive allosteric modulator of GABAA receptors and shows hypnotic effects. Biochemical and biophysical research communications 413 : 637-642.

164. Kim DC, Choi SY, Kim SH, Yun BS, Yoo ID, et al. (2006) Isoliquiritigenin selectively inhibits $\mathrm{H}(2)$ histamine receptor signaling. Mol Pharmacol 70: 493-500.

165. Vazquez-Rodriguez S, Matos MJ, Santana L, Uriarte E, Borges F, et al. (2013) Chalcone-based derivatives as new scaffolds for hA3 adenosine receptor antagonists. J Pharm Pharmacol 65: 697-703.

166. Balsera B, Mulet J, Fernandez-Carvajal A, de la Torre-Martinez R, FerrerMontiel A, et al. (2014) Chalcones as positive allosteric modulators of alpha7 nicotinic acetylcholine receptors: a new target for a privileged structure. European journal of medicinal chemistry 86: 724-739.

167. Gottesman MM, Fojo T, Bates SE (2002) Multidrug resistance in cancer: role of ATP-dependent transporters. Nat Rev Cancer 2: 48-58.

168. Han Y, Riwanto M, Go ML, Ee PL (2008) Modulation of breast cancer resistance protein (BCRP/ABCG2) by non-basic chalcone analogues. European journal of pharmaceutical sciences 35: 30-41.

169. Rangel LP, Winter E, Gauthier C, Terreux R, Chiaradia-Delatorre LD, et al (2013) New structure-activity relationships of chalcone inhibitors of breast cancer resistance protein: polyspecificity toward inhibition and critical substitutions against cytotoxicity. Drug design, development and therapy 7 : 1043-1052.

170. Winter E, Devantier Neuenfeldt P, Chiaradia-Delatorre LD, Gauthier C Yunes RA, et al. (2014) Symmetric bis-chalcones as a new type of breast cancer resistance protein inhibitors with a mechanism different from that of chromones. Journal of medicinal chemistry 57: 2930-2941.

171.Liu XL, Tee HW, Go ML (2008) Functionalized chalcones as selective inhibitors of P-glycoprotein and breast cancer resistance protein. Bioorg Med Chem 16: 171-180.

172. Gu X, Ren Z, Tang X, Peng H, Ma Y, et al. (2012) Synthesis and biological evaluation of bifendate-chalcone hybrids as a new class of potential P-glycoprotein inhibitors. Bioorg Med Chem 20: 2540-2548.
173.Gu X, Ren Z, Peng H, Peng S, Zhang Y (2014) Bifendate-chalcone hybrids: a new class of potential dual inhibitors of P-glycoprotein and breast cancer resistance protein. Biochem Biophys Res Commun 455: 318-322.

174. Parveen Z, Brunhofer G, Jabeen I, Erker T, Chiba P, et al. (2014) Synthesis, biological evaluation and 3D-QSAR studies of new chalcone derivatives as inhibitors of human P-glycoprotein. Bioorganic \& medicinal chemistry 22: 2311-2319.

175. Pommier $\mathrm{Y}$, Leo E, Zhang $\mathrm{H}$, Marchand C (2010) DNA topoisomerases and their poisoning by anticancer and antibacterial drugs. Chem Biol 17: 421-433.

176. Akihisa T, Kikuchi T, Nagai H, Ishii K, Tabata K, et al. (2011) 4-Hydroxyderricin from Angelica keiskei roots induces caspase-dependent apoptotic cell death in HL60 human leukemia cells. J Oleo Sci 60: 71-77.

177. Na Y, Nam JM (2011) Synthesis and topoisomerase II inhibitory and cytotoxic activity of oxiranylmethoxy- and thiiranylmethoxy-chalcone derivatives. Bioorg Med Chem Lett 21: 211-214

178. Park SH, Kim ND, Jung JK, Lee CK, Han SB, et al. (2012) Myeloid differentiation 2 as a therapeutic target of inflammatory disorders. Pharmacol Ther 133: 291-298.

179. Roh E, Lee HS, Kwak JA, Hong JT, Nam SY, et al. (2011) MD-2 as the target of nonlipid chalcone in the inhibition of endotoxin LPS-induced TLR4 activity. $J$ Infect Dis 203: 1012-1020.

180. Wang Y, Shan X, Chen G, Jiang L, Wang Z, et al. (2015) MD-2 as the target of a novel small molecule, $\mathrm{L} 6 \mathrm{H} 2$, in the attenuation of LPS-induced inflammatory response and sepsis. Br J Pharmacol 172: 4391-4405.

181. Stoll R, Renner C, Hansen S, Palme S, Klein C, et al. (2001) Chalcone derivatives antagonize interactions between the human oncoprotein MDM2 and p53. Biochemistry 40: 336-344.

182. Barter PJ, Kastelein JJ (2006) Targeting cholesteryl ester transfer protein for the prevention and management of cardiovascular disease. J Am Coll Cardiol 47: 492-499.

183. Hirata H, Takazumi K, Segawa S, Okada Y, Kobayashi N, et al. (2012) Xanthohumol, a prenylated chalcone from Humulus lupulus L., inhibits cholesteryl ester transfer protein. Food Chem 134: 1432-1437.

184.Duarte CD, Barreiro EJ, Fraga CA (2007) Privileged structures: a usefu concept for the rational design of new lead drug candidates. Mini Rev Med Chem 7: 1108-1119.

185. Bajda M, Guzior N, Ignasik M, Malawska B (2011) Multi-target-directed ligands in Alzheimer's disease treatment. Curr Med Chem 18: 4949-4975. 